\title{
Use of Ecohydraulic-Based Mesohabitat Classification and Fish Species Traits for Stream Restoration Design
}

\author{
John S. Schwartz \\ Department of Civil and Environmental Engineering, The University of Tennessee, 413 John D Tickle \\ Engineering Building, Knoxville, TN 37996, USA; jschwart@utk.edu; Tel.: +1-865-974-7721 \\ Academic Editor: Andreas N. Angelakis \\ Received: 20 July 2016; Accepted: 21 October 2016; Published: 8 November 2016
}

\begin{abstract}
Stream restoration practice typically relies on a geomorphological design approach in which the integration of ecological criteria is limited and generally qualitative, although the most commonly stated project objective is to restore biological integrity by enhancing habitat and water quality. Restoration has achieved mixed results in terms of ecological successes and it is evident that improved methodologies for assessment and design are needed. A design approach is suggested for mesohabitat restoration based on a review and integration of fundamental processes associated with: (1) lotic ecological concepts; (2) applied geomorphic processes for mesohabitat self-maintenance; (3) multidimensional hydraulics and habitat suitability modeling; (4) species functional traits correlated with fish mesohabitat use; and (5) multi-stage ecohydraulics-based mesohabitat classification. Classification of mesohabitat units demonstrated in this article were based on fish preferences specifically linked to functional trait strategies (i.e., feeding resting, evasion, spawning, and flow refugia), recognizing that habitat preferences shift by season and flow stage. A multi-stage classification scheme developed under this premise provides the basic "building blocks" for ecological design criteria for stream restoration. The scheme was developed for Midwest US prairie streams, but the conceptual framework for mesohabitat classification and functional traits analysis can be applied to other ecoregions.
\end{abstract}

Keywords: stream restoration; species functional traits; fish mesohabitat classification; Midwest stream habitat; stream ecology; habitat suitability; ecohydraulics; patch dynamics

\section{Introduction}

Since the 1990s, stream restoration practice in the Unites States (US) has grown significantly, largely motivated by goals to: improve instream habitat, riparian corridors and water quality, comply with regulations for compensatory mitigation, stabilize channels and banks for land and infrastructure protection, remove fish passage barriers, and enhance aesthetics in urban corridors [1-5]. It must be noted that "restoration" is now broadly used by practitioners in the US to include rehabilitation, revitalization, naturalization, and other river engineering activities. The natural channel design (NCD) approach is the mostly widely used methodology, which requires a reference stream reach as an analog and applied dimensionless geomorphic ratios for planform and channel forms [6-10]. Other restoration design approaches rely on hydrologic/hydraulic analysis coupled with geomorphic principles [11-13]. Practitioners use these approaches to reconfigure channels and commonly install hard structures in order to adjust sediment transport capacity and create stable morphologies [14-16]. Ecological concepts may be incorporated into design but procedures are less methodical predominantly relying on available bioassessment data and professional judgement to place various habitat features. Though the physical sciences are employed to a greater extent than the ecological sciences, the most commonly stated objective for projects is to restore the biological integrity by enhancing habitat and water quality $[4,5]$. However, recovery of biological integrity from restorations has been mixed depending on how 
initial project goals were defined, and the organism group (i.e., fish, macroinvertebrates, mussels, periphyton) used to assess outcomes [1,17-24]. Considering the current practices and reported project biological responses, improvements are needed on how to incorporate ecological criteria into the restoration design process, and better understand the potential capacity for ecological recovery within stressed ecosystems.

When ecology is considered in stream restoration design, fluvial geomorphology, engineering hydraulics, and aquatic ecology are generally applied sequentially in this listed order (Figure 1a). This linear design thinking tends to rely on the "build it and they will come" premise for ecological considerations $[25,26]$. The NCD approach assumes that the selected geomorphic reference provides the physical habitat template needed to enhance the restored reach's biological integrity, but this may not always be the case. For example in low-gradient alluvial streams, construction of weirs to scour a pool (e.g., J-hook and V-cross vanes) may benefit pool habitat species, but riffle habitat specialists may be compromised if the weir reduces riffle length immediately upstream by creating a long backwater glide [19]. Even with favorable restored habitat, the potential species pool for recolonization is dependent on the watershed-scale multiple stressors and reach-scale barriers limiting dispersal [21,27-31]. Recolonization potential at the watershed-scale can be evaluated if adequate bioassessment data are available, and such data are also useful for project scoping [10,24]. Bioassessments guide what basic ecological concepts are incorporated into the geomorphic design, but generally lack the detailed pre-design ecological data needed to specifically target habitat needs. Data needed includes field surveys of sequentially-mapped mesohabitat units and biota; in addition to the use of habitat suitability criteria (HSC) for target species-habitat relationships applied in hydraulic habitat models [32].

a)

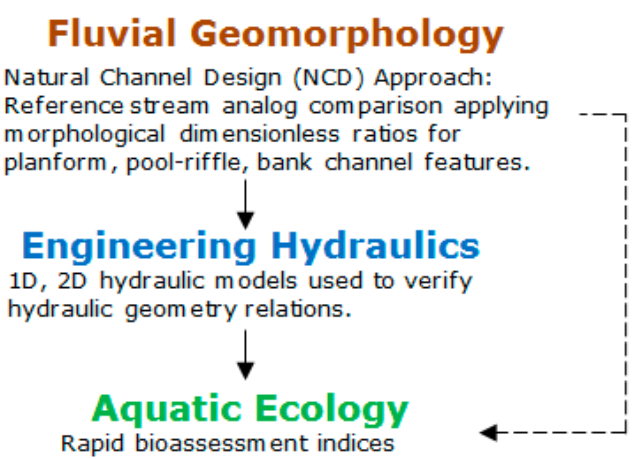

Rapid bioassessment indices

for habitat and biota.

b)

Fluvial Geomorphology

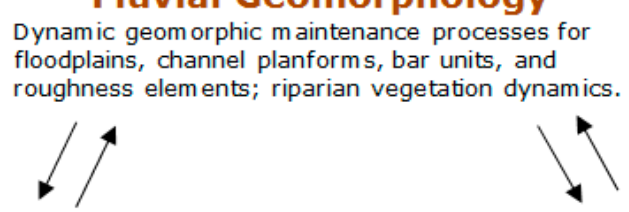

Engineering Hydraulics

2D, 3D hydraulic models, and multi-stage ecohydraulic relations with habitat suitability parameters; coherent turbulence structure; hydraulic geometry relations.

\section{Aquatic Ecology}

$\longleftarrow$ Functional traits analysis and life history pattern summation for target species and/or biota assemblages; multiple stressor analysis; ecohydraulic mesohabitat classification.

Figure 1. Multidisciplinary design processes for stream restoration: (a) as commonly practiced; and (b) per an ecohydraulics mesohabitat approach.

\subsection{Ecological Concepts: Broad Applications for Stream Restoration}

Lake et al. (2007) [33] summarized ecological concepts that are, or can be used to broadly guide stream restoration designs, noting spatial scale and associated processes are critical to project success. Biota distribution and abundance are governed by physical habitat structure spatially organized 
within a hierarchical structure and each subsequent scale consisting of geomorphic and ecological processes [34-37]. Frissell et al. (1986) [38] describes the classic view of this hierarchical structure within a watershed from segment, reach, channel (pool-riffle) unit to the microhabitat channel bed scale. Physical habitat structure at the reach and channel unit scales can provide refugia from hydrological disturbances (floods and droughts) enhancing ecosystem resilience [27]. The episodic nature of habitat characteristics with respect to flow and other environmental conditions is described by the Patch Dynamics Concept, where the spatio-temporal dynamics of favorable habitat space for biota varies in frequency and duration [39-42]. Patch dynamics recognizes the dominance of abiotic controls on biotic communities associated with habitat heterogeneity, and these controls under natural disturbance regimes promote biodiversity [43]. In general, restoration designs that apply these concepts aim to increase habitat heterogeneity, typically channel reconfiguration and use of instream structures, i.e., weirs, logs, root wads, and lunkers [44,45].

Connectivity within a watershed's riverine corridor can be viewed multidimensionally per longitudinal, lateral, and vertical dimensions, which influence food webs and trophic structure [37,46-49]. The River Continuum Concept [50] as the framework for longitudinal connectivity describes the shifts in tropic dynamics and organism assemblages correlated with allochthonous organic sources in the headwaters to more autochthonous sources in less shaded, larger downstream reaches. To note, this river continuum is inverted in prairie watersheds of the Midwest US [51]. The Flood Pulse Concept [52] describes ecological processes associated with lateral connectivity between the channel and floodplain among different hydrological regimes. Recently more attention has been given to vertical connectivity with stream restoration, characterizing the potential influence of the hyporheic zone on water quality and nutrient reduction [53-56]. Understanding organic matter processing, nutrient cycling, and water quality are all important ecological considerations for stream restoration design [57]. General ecological application of these multidimensional concepts consist of channel modifications with an aim to reduce habitat fragmentation, reconnect the channel with the floodplain for high flows, provide riffle habitat, and revegetate the riparian corridor.

\subsection{Habitat and Biological Assessments}

Habitat composition and quality are assessed through field surveys that rely on mesohabitat classification schemes, visually identifying habitat units, e.g., pools, riffles, glides, rapids, etc. [58-65]. Environmental agencies accompany mesohabitat surveys with biological surveys for fish and/or macroinvertebrates typically, and both surveys are used to compare with reference stream conditions to generally assess a stream reach's biological integrity [65,66]. Studies assessing the ecological health of streams have extensively relied on linkages between physical habitat quality and biota composition [22,66-70]. Kaufmann et al. (1999) [64] described a field protocol of longitudinally mapping mesohabitat units in sequence, and collecting basic dimensions of each unit and information on riparian vegetation and microhabitat features, i.e., large woody debris (LWD), overhanging bank vegetation, and large rocks. In alluvial systems with less than $2 \%$ grade, pool-riffle sequences along the channel bed are a dominant geomorphic and habitat feature if undisturbed [71-76]. Ecologically, pools and riffles are essential because so many lotic species have evolved their body morphology and behaviors to specifically occupy one unit or the other [77-79]. Because projects commonly involve channel reconfigurations at the reach-scale, pool-riffle sequences become a key morphological structure for restoration design $[2-5,19]$. Success of restoration projects with habitat enhancement objectives requires mesohabitat units to be designed such that geomorphic and hydraulic principles are applied for long-term dynamic stability by self-regulating maintenance processes [32,80,81]. In addition, ecological success of projects may require more detailed information on species-habitat relationships for target species or biota assemblages during the pre-design process.

Recently in the US, there has been a growing need to better assess ecological successes from stream restoration projects, largely driven by the compensatory mitigation regulations under Section 404 of the Clean Water Act [82,83]. Administered by the US Army Corps of Engineers through project 
permitting, required compensation for loss of stream functions from anthropogenic impacts are offset by restoration in a nearby stream. Under the 2008 Federal Mitigation Rule, mitigation credits used in stream restoration banks require assessing loss of stream functions and quantifying gains from restoration. The difference between restoration gains and pre-restoration losses has been termed "functional lift", where Harmon et al. (2012) [83] frames the analysis protocols as a stream functions pyramid and functional metrics are composited into a score, or lift. The pyramid framework is founded on geology and climate, and consists of five categorical levels with hydrology at its base, and sequentially followed by hydraulics, geomorphology, physicochemical or water quality, and lastly biology. It also relies on NCD methodology for geomorphic metrics, and bioassessments consisting of indices of biotic integrity (IBI) and habitat quality metrics [66]. Expanding on this list of stream functional metrics, many of which are surrogate measures for biological integrity, others have proposed attributes for restoration success as bioindicators focused on assessing ecological processes [4,84-87]. Many of these ecological-process measures are valuable (i.e., primary production, organic matter budgets), but would rarely be used by practitioners due to the expense of data collection and analysis. Hence, the relevance on commonly available bioassessments and habitat quality index scores which are useful for project scoping, and provide general guidance for restoration. As noted in the Introduction above, bioassessment indices need to be disaggregated in order to provide useful pre-design data specifying detailed habitat needs for target species or biota assemblages.

\subsection{Hydraulic Habitat Modeling}

Hydraulic habitat modeling serves two functions that can be applied to stream restoration design; they are: (1) hydraulic models provide valuable information on geomorphic maintenance processes associated with mesohabitat physical structure; and (2) habitat models utilizing HSC provide the means to apply ecohydraulic principles [88-91]. Mesohabitat preferences by aquatic biota are defined by HSC in which preferences are associated with channel morphology, flow, habitat cover, and physiochemical conditions [92-95]. Among various aquatic organism groups, HSC are most commonly developed for adult fish. Other fish HSC have included multiple life stages, e.g., juveniles, larval, and egg (spawning). Preference relationships primarily include water depth, downstream-orientated velocity, and dominant substrate types where species-specific preferences are scaled from no preference to fully favorable preferred conditions ( 0 to 1 , respectively). Location preferences for fish species are obtained through biological field surveys utilizing pre-positioned areal electrofishing devices (PAEDs) [96]. Developed originally for instream flow incremental methodology in regulated rivers, the Physical Habitat Simulation (PHABSIM) model provides the methodology to link HSC with different flow regimes and channel conditions [93]. With mapped bed substrate types and modeled water depth and velocities for designed channel areas, species preferences per area are summed over the stream reach to generate a single metric termed "weighed usable area" (WUA). PHABSIM is a one-dimensional (1D) model, and limited in application for explicit WUA computations in lateral and floodplain habitats $[97,98]$.

Multidimensional hydraulic models utilizing computational fluid dynamics applications on desktop computers have become more readily available since the 2000s. Tonina and Jorde (2013) [99] reviewed the application of 1D, 2D, and 3D hydraulic models for ecohydraulic studies; in addition to non-numerical models. Hydraulic 2D models based on the depth-averaged St. Venant equation are useful for restoration providing design information in both the longitudinal and lateral dimensions [100-102]. The River2D model also includes a habitat subroutine computing WUAs based on species preference relationships at each user-defined flow cell $[103,104]$. Non-numerical approaches rely on field surveys coupled with fish occupancy data per classified mesohabitat unit and obtained from PAEDs, e.g., MesoHABSIM [105,106]. They apply statistics to develop multivariate relationships among HSC, habitat hydraulics, and physical features to predict fish occupancy, which can used in channel habitat design [107]. The use of hydraulic habitat models expands the design toolbox for stream restoration, integrating principles from three fundamental disciplines: fluvial geomorphology, 
engineering hydraulics, and aquatic ecology (Figure 1b). This approach may consider life histories and trait-habitat relationships for target species, or more broadly a composition of biota assemblages but after the geomorphic design parameters have been determined $[32,108,109]$. Restoring stream habitat based on geomorphic classification of stream reaches can be limiting [29], but coupled with a hydraulic habitat model, species trait-based HSC can be incorporated into restoration design. In general, ecohydraulic models have been used in restoration projects, but their use is minor when considered with the number of projects constructed each year using the NCD method [19,91,102,110-112].

\subsection{Developing Ecological Criteria for Stream Restoration Design}

It has been suggested that ecological criteria for reach-scale restoration designs could be improved through the use of an ecohydraulic-based mesohabitat survey and species functional traits analysis, including a watershed assessment of the available species pool for recolonization [32]. A trait-based analysis can be completed by specifically linking physical habitat structures with basic biological needs of stream organisms, and fully utilizing existing autecology information on organisms from the potential recolonization pool [20,113-118]. Why an organism occupies a particular stream location at a given time is therefore influenced predominantly by specific channel morphologies and hydraulic conditions [77,80,88,119-124]. Within specific channel morphologies and hydraulic conditions, each species has a unique relationship to the different characteristics of physical stream habitat in order to find the basic biological resources for survival, e.g., food, reproduction, and shelter. Using fish as the "model" organism group, biological resources as trait strategies include: feeding, resting, evasion (escape from predation), spawning, and flow refugia (Table 1). Channel flow patterns have a dominant influence on the organization of biological communities where organisms have evolved to lotic environments that are heterogeneous and temporally variable [43]. The more heterogeneous and complex the physical habitat structure, the greater potential for different species-habitat relationships to occur, which ultimately create more diverse biological communities [21,125-127]. By identifying these relationships based on species functional traits, the ecological significance of process-based hydraulic and geomorphic measures can be systemically developed as ecological design criteria.

This article reviews key principles for stream mesohabitat restoration with an emphasis on integrating fluvial geomorphology, engineering hydraulics, and aquatic ecology; and organized by a fish 'biological needs' framework as presented in Table 1. A multi-stage mesohabitat classification scheme provides the essential link needed to integrate ecohydraulic principles with basic biological needs and geomorphic processes associated with habitat maintenance (Figure 1b). This review focuses on these key principles for Midwest US prairie streams with the objective to demonstrate as a case "region" the fundamental process linkages needed to develop ecological design criteria for mesohabitat enhancement. The linkages are summarized by the following topics:

- Applied geomorphic processes for mesohabitat self-maintenance;

- Mesohabitat-scale ecological concepts;

- Species functional traits relationships with mesohabitats; and

- Ecohydraulic-based, multiple flow-stage mesohabitat classification.

To note, these linkages must be developed conceptually for different physiographic regions with a comprehensive understanding of life histories and traits of the regional species pool. Midwest headwater streams are low-gradient alluvial systems, commonly lack LWD and extensive woody riparian vegetation, and have diverse fish species assemblages. Although this review uses fish as the organism group, macroinvertebrates and other groups can be applied with goals to improve upon ecological criteria for stream restoration design. 
Table 1. Basic biological needs or trait strategies for fish guilds organized by flow condition and season: an example for low-gradient alluvial streams in the Midwest US.

\begin{tabular}{ccc}
\hline \multirow{2}{*}{ Stream Flow Condition } & \multicolumn{2}{c}{ Season } \\
\cline { 2 - 3 } & Summer/Fall & Winter \\
\hline \multirow{2}{*}{ Low and Moderate Base Flows } & Feeding & \\
& Resting & Temperature Refuge \\
& Escape from Predation & \\
\hline High Flows-Floods & Spawning & Flow Refuge \\
\hline
\end{tabular}

\section{Applied Geomorphic Processes for Mesohabitat Maintenance}

Two geomorphic scales are relevant to the maintenance processes of mesohabitat units; they are the channel unit (pool-riffle) scale situated hierarchically within the planform (reach) scale $[38,128]$. Channel units are in the length scale of approximately 1-100 channel widths and reaches are 100-1000 channel widths [35]. In general for the Midwest US, planform types are classified as straight or meandering, and rarely braided [36]. Valley structure and floodplain-channel dynamics exert geomorphic controls on the channel by fixing the longitudinal gradient, and regulating the rate of sediment delivery to the channel. Channel morphology within planforms, including cross-sectional capacity [71,128,129], meander characteristics [130], and local longitudinal profile [131] are dynamically maintained by flood flow events occurring on average every 1-2 years. These flood flows are termed dominant discharge, but practitioners commonly refer to these flows as the bankfull discharge $[10,132]$.

Floodplains are formed by geomorphic processes balancing sediment transport and deposition during flood events and governed by the force-resistance properties of the channel and adjacent riparian areas [129,133-135]. Force is represented as stream power, and resistance consists of a multitude of factors including vegetation, sediment load coarseness, human interventions, etc. Nanson and Croke (1992) [135] classified floodplains based on stream power (energy) and sediment deposition as high- and medium-energy non-cohesive and low-energy cohesive surfaces. Relevant to this review for high-flow habitat refugia are two floodplain process types within the medium-energy non-cohesive classification where stream power ranges from 10 to $60 \mathrm{~W} \cdot \mathrm{m}^{-1}$. The three floodplain types in meandering channels and associated geomorphic processes at the channel-floodplain interface include:

- Lateral Migrating Floodplains: Lateral point-bar accretion consisting of progressive sediment deposition on the convex bank of a meander bend from helical and divergent flow through the bend [136], which creates elevated and vegetated remnant point bar surfaces;

- Counterpoint Floodplains: Counterpoint accretion occurs within a hydraulic recirculation zone (or large stream eddy) formed against the upstream limb of the convex bank in sharply curving and active migrating bends allowing for fine sediment deposition, which over time form an elevated and vegetated concave bank bench [134]; and

- Abandoned Channel Floodplains: Abandoned-channel accretion occurs in actively migrating channels creating cutoffs followed by overbank vertical accretion, which depending on sediment deposition and location to the active channel the floodplains features include elevated and vegetated remnant channels, and a backwater slough near the mouth of the original channel [137].

Planform characteristics have some control over the regularity of pool spacing $[71,128]$. For example, in meandering streams with single-loop geometry, pool spacing is highly correlated with meander wavelength, where pools occur at each bend. Within planform reaches, pool-riffle sequences are a product of a mobile gravel-sand bed, in which longitudinally orientated cyclic patterns of erosion and deposition result in pools as local topographic lows and riffles as topographic highs [131]. Pool spacing occurs on average every 5-7 channel unit widths, but the reported range is 1.5 to 23 [72]. Pool-riffle morphology with its unique fluvial properties and spatial pattern represents a stable, but 
dynamically-varied equilibrium state for channel bed morphology [73-76]. Geomorphic attributes associated with bankfull discharge and pool spacing as noted above are common knowledge and widely applied in the NCD approach for stream restoration [10,44,45].

Less applied directly in restoration design is the velocity-reversal hypothesis, and is the fundamental concept for pool and riffle morphological self-maintenance. This hypothesis defines that during low-flow stages velocities in pools are slow and riffles are relatively fast, and near bankfull high-flows velocities transition where pools are fast and riffles are slow [76,138-143]. A reversal in bed shear stress also occurs from low- to high-flow stages resulting in bed scour in pools and bedload deposition in riffles during high flows. Thus, pools can be distinguished from riffles by their sediment properties, where pools contain more fines and riffles contain a mixed bedload with course gravels and sand. It should be noted that velocity and near-bed shear stress reversals was originally conceived from a 1D hydraulic perspective and based on unit averages.

Geomorphic form and fluvial processes that maintain this pool-riffle morphology are more accurately viewed by 3D channel hydraulics including downstream, lateral, and vertical velocity vectors [144-148]. Channels without major resistance structures will exhibit helical flow patterns which are fundamental to initiation and maintenance of bar structures [149-151]. Arranged together as a bar unit, pool, riffle, and point bar elements are positioned distinctly in a channel meander bend [136]. Pools are located along the outer bank just downstream of the bend apex, riffles are located between bend apices, and point bars are located along the inner bank across from the bend apex. As flow enters the bend it shoals over the point bar forcing flow at the water surface to be directed outward towards the outer bank. In channels without large resistance structures, flow acceleration and deceleration occurs through a pool where flow resistance forms a small, secondary circulation cell with lateral velocities directed toward the inner bank at the water surface. A helical pattern of flow develops through a meander exhibited by transverse or secondary velocity vectors coupled with dominant downstream vectors. It should be noted that multiple helical flows cells can occur in straight channels and the number is dependent on channel width and boundary roughness [152].

Recent studies utilizing 2D and 3D hydraulic models have demonstrated the dominant role of nonuniform flow, secondary circulation patterns, and coherent turbulent structures influencing pool-riffle maintenance processes [152-159]. Expanding to a multidimensional view of hydraulics and sediment routing through pool-riffle, morphological maintenance is explained by flow acceleration at the pool head's cross-sectional constriction during high flows, where flow convergence with maximum velocities and sediment are directed over the point bar rather than the pool thalweg. Whether flow convergence is directed over the point bar is likely dependent on planform, local morphology at the pool entrance, and flow stage, which govern formation of a separation zone and hydraulic recirculation zone over a submerged point bar. It appears flow convergence at the pool head is the dominant driver for development of a secondary circulation cell in the mid-pool area where water depth is deepest, and secondary circulation mobilizes fine sediment $[152,154]$. Flow deceleration is initiated following the pool front per expanding cross-sectional area and bed slope drop, where MacVicar and Roy (2011) [156] notes from field measurements deceleration correlated spatially with high levels of turbulence intensity. At the tail end of the pool or pool rear, flow deceleration and secondary circulation divergence leads to course sediment deposition into the riffle. Recent interpretation of 3D flow dynamics through the pool suggests that unique ecohydraulic relationships exist among the pool-front, -mid, and -rear areas, in addition to the submerged bar and riffle areas. With the use of a 2D or 3D hydraulic model, maintenance processes associated with velocity- and shear-reversal and flow acceleration-deceleration concepts can be tested during restoration design [19,91,102,159].

While pool spacing is regular in less complex stream reach morphologies where 3D helical flow patterns develop, spacing can be influenced by instream channel structures [128,143]. In streams with large roughness elements, velocity vectors and turbulence intensities scale to these elements, and appear to prevent development of reach-scale 3D helical patterns [91,160]. Scour of alluvial beds occurs very locally from various roughness elements, i.e., LWD, bedrock outcrops, and boulders, which 
impose a strong local control on pool spacing $[139,161]$. Pool types have been defined by the formative structure per roughness element or channel feature [162]. The size of the scour zone is dependent of the relative size of the roughness element in relation to channel width, and channel gradient $[163,164]$. And the spatial position of the scour pool is influenced by local sediment deposition patterns, both longitudinally and laterally [73-76]. Overall, this variability in longitudinal pool spacing is subject to heterogeneity of flow resistance characteristics including the stochastic inputs of large roughness structures to the stream channel and composition of sediment loads. Placement of in-channel structures must be considered during restoration design and appropriately integrated with planform-scale hydraulics, and the number of structures must be related to the available stream power to achieve the channel design outcomes.

\section{Applied Ecological Concepts at the Mesohabitat Scale}

Many abiotic and biotic environmental factors collectively regulate fish distribution and abundance in streams $[122,125,165]$. These factors include:

- habitat selection and relative availability of structural requirements in terms of complexity, duration, frequency, and juxtaposition;

- abiotic disturbances such as extremes in flows and temperature; and physiological tolerances to local water quality conditions;

- food availability and food-space-cover relationships;

- resource specialization of fish species; species traits related to body morphology and mode of foraging;

- $\quad$ predator-prey interactions and trophic controls, intra-and inter-specific competitive interactions related to individual size and behavior, and population densities; and

- immigration-extinction and recolonization dynamics.

Fish distribution and abundance are highly variable both temporally and spatially as a function of the multivariate nature of these environmental factors [28,166-169]. The Patch Dynamics Concept offers a valuable perspective of spatiotemporal nature of mesohabitat structure and organism occupancy [40,170,171].

A patch is a spatial unit occupied by an organism and determined by its resource needs [39-42]. It remains subject to scale-dependent functional relationships between biotic interactions and abiotic environmental factors. A patch emphasizes the heterogeneous nature of physical habitat structure, and the temporal changes as environmental conditions vary. Its variable use by individual organisms is a function of spatiotemporal favorability, or less harshness in terms of lotic disturbance regimes [78]. The heterogeneous nature of stream habitat shapes a patch with irregular boundaries, contracting and expanding with the change in flow stage. Because a patch is defined by an organism's resource needs, its space is defined by an ecological process or functional attribute, and has seasonal limits based on individual species' life history and traits. Poff (1997) [114] suggests that species traits data linked with physical habitat attributes can be used to "filter" organism distribution hierarchically among regions and within watersheds. Figure 2 illustrates the importance of the regional species pools and how watershed-scale habitat fragmentation from multiple stressors can influence patch occupancy, in addition to its relevance to stream restoration.

Temporal variability of fish community structure is observed at multiple time scales from hours to years, but within the conceptual framework for mesohabitat use in this article the relevant time scales are the seasonal and flood periods (Table 1). Seasonal fluctuations in fish community structure generally follow a repeatable annual pattern regulated by each species' life history pattern [172-177]. Seasonal fluctuations have been observed in Midwest headwater streams, where fish species richness was greatest in late summer and fall compared to the spring when it was lowest $[178,179]$. During the winter, mesohabitat use by fish was observed to be preliminarily in deep pools [32]. Expression of species traits and trophic structure strategy are generally related to annual hydrologic variability 
among different US regions [180]. Poff and Allan (1995) [119] observed hydrologically "stable" streams with fish assemblages characterized as trophic specialists associated with moderate to fast velocities in permanent flows, and hydrologically "variable" streams with fish assemblages characterized as trophic generalists associated with slow velocities in headwater reaches. In part, spatial relations to fish distribution in a watershed and expression of species functional traits cannot be separated from temporal patterns of organization.

\section{a)}

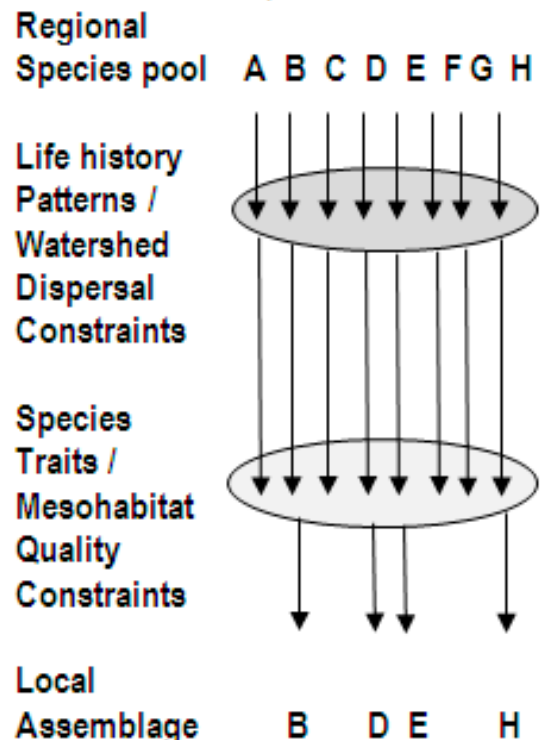

b)
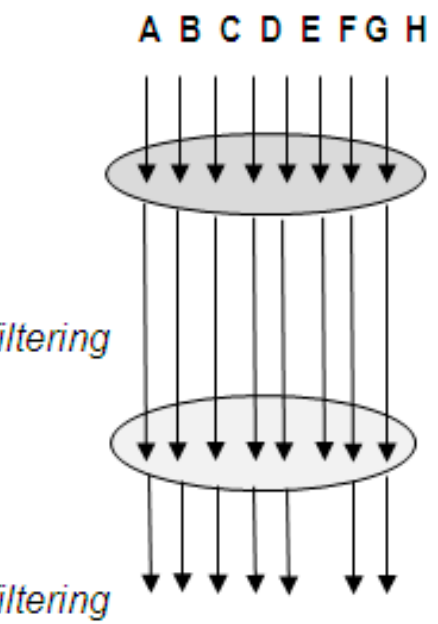

A B C DE G H c)

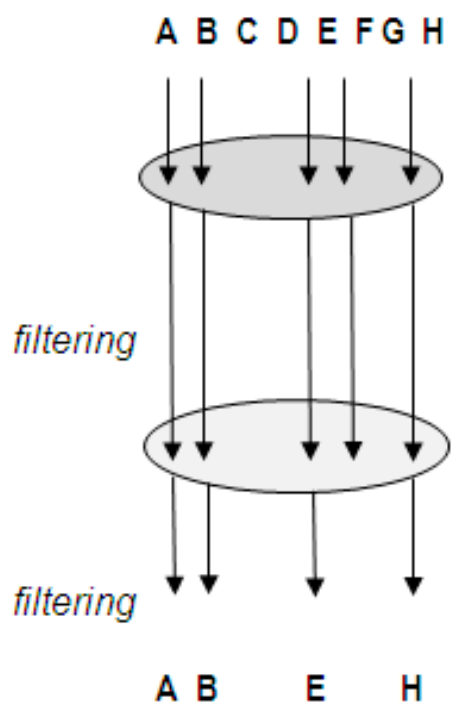

Figure 2. Conceptual basis for a gap analysis for a reach-scale habitat restoration using hypothetical outcomes for: (a) no watershed-scale stressors or dispersal constraints and mesohabitat degradation; (b) no watershed-scale stressors or dispersal constraints and mesohabitat restoration; and (c) watershed-scale stressors and mesohabitat restoration (adapted from Lake et al. (2007) [33]; Poff (1997) [114]; and Belya and Lancaster (1999) [115]).

Flow variability and its effect on stability of fish assemblages have been extensively discussed in relation to extreme flow events, i.e., floods and droughts $[181,182]$. During floods, habitat selection by fish in Midwestern rivers have been grouped by preference guilds consisting of flood-exploitative species that move onto inundated floodplain and flood-quiescent species that remain in the channel with reduced activity $[183,184]$. The spatial arrangement of flow refuge within a watershed, and in particular in floodplain areas, appears to be essential for resilience and recovery of fish communities from natural flow disturbances [185-187]. In headwater streams, fish assemblages were observed to be stable and persist over years even after catastrophic floods [188-190], and severe drought conditions [191]. During floods, physical habitat complexity in pools create hydraulic eddies providing shelter as flow refugia. During severe droughts, deep pools provided refuge sites with sufficient water after stream flows ceased and riffles have dried. Fish community structure has evolved over eons adapting to hydrological frequency of extreme flow events correlated with the local geomorphological structure that can provide refuge.

Geomorphological structure, as a scale-dependent abiotic environmental factor strongly regulates fish distribution in watersheds and habitat use patterns that are hierarchically nested [122,125,192]. Within the mesohabitat scale, differential habitat use by fish between pools and riffles has been extensively studied [77,123,175,193-199]. It was observed from these studies that pools and riffles locally diversify lotic conditions providing strong abiotic environmental controls on fish distribution and abundance. For example, in the Pacific Northwest US, coho salmon juveniles and cutthroat trout occupy pools whereas steelhead juveniles occupy riffles [200]. In the Midwest US for example, 
centrarchid species occupy pools and darter species will occupy riffles $[179,197]$. Spatial segregation by fish between pool and riffle habitats is also influenced by several biotic factors including predator-prey interactions [194,201], interspecific competition or aggression [202,203], differential body size and body morphology related to energetics of maintaining position in different hydraulic conditions $[78,200,204]$, and innate habitat preferences. Riffles and lateral shallow areas such as submerged point bars provide cover for smaller fish from larger predatory fish $[205,206]$. Organization of fish assemblages are also associated longitudinally within ecotones between pools and riffles, and laterally per microhabitat complexity, i.e., cover or substrate [77,124,196,207-211].

Recognizing the influence of local hydraulics at the local channel scale, velocity and water depth were used together to associate fish assemblages among pool, riffle, and glide habitats $[197,200,203,206,212,213]$. Fish preference relationships with local hydraulics are typically measured as depth-averaged velocities in the downstream direction at a single location, along with the total water depth [93]. Based on these same fluvial attributes of velocity and depth, Bain et al. [207] separated fish preference guilds into a habitat specialist that preferred slow velocity and shallow depth, and a habitat generalist that preferred fast or slow water and deep depths. In other studies, habitat preference guilds included differentiating life stage of a fish species, as young-of-the-year and juveniles selected slow velocity, shallow water habitats $[197,204]$. Local hydraulics influence fish habitat use directly or indirectly based on various biological needs, such as food resources [209,214,215], predation cover [210,216], and spawning requirements [217]. These studies referenced above provide the ecohydraulics perspective for fish habitat use and application for restoration design [80,218-220].

\section{Species Functional Traits}

In the previous section on ecological concepts, species functional traits were interrelated with species-habitat relationships, species distribution and abundance, and suitability criteria for preferential mesohabitat use, i.e., water depth, velocity, substrate; proximity to instream structural elements; and bank vegetative cover [113,116,221-226]. This section expands on the review of fish trait-based concepts because of its key role for the development of multi-stage ecohydraulic-based mesohabitat classification schemes. Importantly, classification needs to recognize species-habitat relationships within the variable nature of lotic environments and habitat favorability per organism as reflected in the Patch Dynamics Concept.

Frimpong and Angermeier (2010) [113] provided a detailed review of fish species traits and the theoretical and applied use in studies supporting the development of bioassessment protocols with indices of biotic integrity (IBI), linking species responses to habitat degradation, and interpreting mechanisms of assemblage structure and community ecology. They also suggested that species traits could be used in general assessment rules forming the basis of management and conservation tools, including species recovery through restoration. A key objective of this review is to demonstrate how species traits, with the integration of geomorphic and ecohydraulic principles can be used to better define mesohabitat units for restoration assessment and design. Understanding basic definitions associated with traits supports this review's objective. Formally, a trait is defined biologically as the physiological requirements, morphological adaptations, and life histories innate to a species; and ecologically as the species' environmental preferences and associated behaviors $[113,227,228]$. McGill et al. (2006) [228] defines a functional trait as a species trait that strongly influences organism performance, fitness, and/or survival; and that it must be measurable. The use of the terms, species traits and functional traits has been used interchangeably in literature [113].

With fish community ecology, the Guild Concept is most applicable where co-occurring species are aggregated based on their exploitation of a common resource [113,229-231]. The term "functional groups" used primarily for macroinvertebrate communities differs from guilds in that co-occurring species perform a common ecosystem function by their mode of resource utilization, i.e., shedders, scrapers, and collectors. Fish guilds can be grouped by the dominant strategies or daily activities of resource use including feeding (food habitat, diet choices, and/or trophic structure); reproduction 
(spawning), resting, escape from predation (evasion), and shelter (flow refugia). These biological needs or strategies are reflected in Table 1, which define the framework for classifying mesohabitat units in Midwest headwater streams (Section 5 below).

The Guild Concept was applied in the development of the IBI by Karr (1991) [232]. IBI are broadly used in state biomonitoring programs to biologically assess environmental from poor water quality and habitat alteration [233-236]. It compresses categorical metrics for various fish traits (i.e., feeding and reproductive guilds, physiological tolerance) and other ecological indicators (i.e., richness and diversity) into a single score, in which the assessment score is compared with state reference condition scores [237]. The single IBI score is valuable as a screening tool to scope potential restoration projects, but is inadequate for design purposes. Differing from the IBI bioassessment approach, trait-based analyses have been specifically applied to assess habitat degradation by observing shifts in fish community composition, statistically [227,238-243]. Assessing levels of degradation with or without the use of a reference comparison, trait-based approaches reduce dimensionally overcoming the cumbersomeness of multispecies statistics. Overall, it is trait-based data interrelated to physical habitat structure within guild categorical metrics that potentially provide the useful information for restoration design.

Further study associated with fish species traits will certainly improve our knowledge of fish ecology and applications for management. Frimpong and Angermeier (2010) [113] suggest future research should aim to advance our understanding of how trait breadth and plasticity relate to fish recruitment and population performance in episodic fluvial environments. In addition, improved statistical techniques for assessing impairment and modeling tools for predicting fish assemblages among local habitat gradients are suggested [242-244]. Though this area has potential for advancement, species traits can effectively be used in stream restoration design by using presence/absence data from field surveys and utilizing a trait database [245]. These data are assessed to determine whether traits are expressed at a proposed project site, or should be based on a reference condition and barring no filtering by watershed-scale stressors (Figure 2). Species traits can be applied in channel restoration designs with the goal of enhancing mesohabitat heterogeneity and fish assemblage diversity, but in doing so it is required that classified mesohabitat units have a functional relationship with trait strategies. Conceptually, trait strategies are associated with mesohabitat structure as defined by unit types, and associations are developed based on HSC and other preference information that are available (Figure 3).

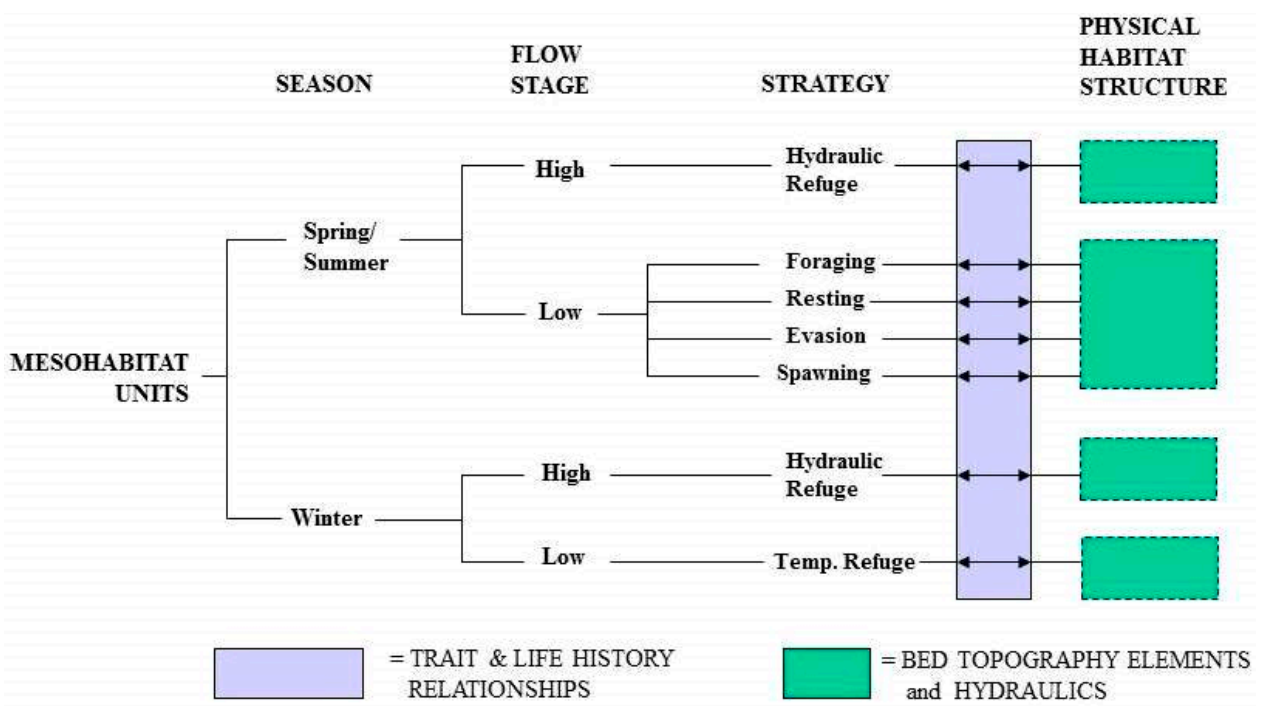

Figure 3. Conceptual framework for developing a mesohabitat classification scheme for low-gradient Midwestern headwater streams applying species trait and life history relationships. 


\section{Multi-Stage Ecohydraulics-Based Mesohabitat Classification}

\subsection{Framework for Classification of Multi-Stage Ecohydraulics-Based Mesohabitat Units}

Mesohabitat unit types are commonly classified as different pool types for slow water, and glides, riffles, rapids, and cascades for fast water $[61,63]$. In-stream delineation criteria for mesohabitats based on low-flow stages rely on water depth, water surface slope and visual turbulence conditions, water velocity, substrate characteristics, and instream structural controls. Pools are differentiated by formative structures, for example LWD that causes formation of a scour hole in the bed during high flows, or a beaver dam that causes a backwater pool at all flow stages [162]. Many mesohabitat classification schemes have been developed presenting modifications to this basic terminology though delineation criteria remain essentially the same [58-61,64,77,246,247]. In general, these existing delineation criteria for mesohabitat unit types among the units rely on geomorphic structures and a 1D view of channel flow at low-flow stages.

Flow or physical biotopes have been used as a term to describe these same mesohabitat units emphasizing hydraulic condition and biota unit use [120,121,246-249]. Based on varying low-flow conditions, ecological criteria have been linked to the mesohabitat classification of "functional habitat units" [120]. Functional habitat units conceptually recognized the importance of varying local hydraulics and its influence on biotic environmental factors. Kocik and Ferreri (1998) [248] conducted a field study applying the Patch Dynamics Concept, and related the spatial arrangement of functional habitat units to fish dispersion and spawning. Though these classification schemes begin to integrate physical habitat space with ecological functions at low flow stages, 3D mesoscale hydraulics patterns are not applied to habitat delineation at both low- and high-flow stages. At higher flow stages, channel hydraulics for the same habitat space change, as well as the fish use and survival strategies [120,250-253]. For example, Wadson and Rowntree (1998) [251] applied the biotope classification system to three different flow stages and reported percentages of pool and riffle units decreased with higher flow stages, while percent glide units increased. Because low-flow habitat units are maintained geomorphologically during the high flow events, there is a direct spatial relationship between habitat units classified at both these flow stages; however little attention has been given to classifying high-flow habitat refugia within a geomorphic process framework [32].

The advantage of applying 3D hydraulic models to mesohabitat classification is that they better represent the fluvial environment experienced by aquatic biota at multiple flow stages. This is a fundamental principle in ecohydraulic applications $[88,90,91]$. Classically, mesohabitat classification schemes have been developed by biologists applying their knowledge of spatial patterns of biota occupancy related to published geomorphic river forms [38,58,61]. Compared with biologists, hydraulic engineers view the fluvial environment through the application of computational fluid dynamic (CFD) models, routing water mass and momentum among a modeler defined numerical mesh space [99]. Turbulence modeled at a micro-scale are a function of Reynolds stresses of fluid motion and boundary layer resistance are scaled to topography and in stream structures [254-259]. Discipline differences are best exemplified by the use of the term "turbulence", where biologists refer to it as "wavy" surface waters as criteria for mesohabitat classification and hydraulic engineers apply CFD at the micro-scale noted above [58,63]. When applying ecohydraulics to mesohabitat classification, it appears that there is a neglected ecohydrogeomorphic scale that occurs between the microhabitat and channel unit (pool-riffle) scales, as defined by the hierarchical habitat framework in Frissell et al. (1986) [38]. Microhabitats are scaled to features on the stream bed $<1 \mathrm{~m}$, i.e., rocks, woody debris, macrophytes, etc., where channel units are scaled to geomorphic forms greater than 1-10 channel unit widths $[35,36,260]$. Relevant to fish use of habitat space and termed as a mesohabitats in this article, 3D hydraulic and turbulence patterns are scaled to large roughness elements (e.g., boulders, LWD) and a length dimension less than one channel unit width $[160,261]$.

In order to improve on existing classification schemes, mesohabitat units should be viewed as patches of irregularly-shaped, three-dimensional space that: (1) vary in shape as a function of 
flow stage consisting of 3D constructs orientated longitudinally and laterally within the channel; (2) provide for the basic resource needs of organisms as a function of species traits; (3) are bounded by bed topography elements regulated by geomorphic processes associated with self-maintenance; and (4) associate habitat suitability with ecohydraulic relationships reflecting mesoscale 3D hydraulic and turbulence patterns. These criteria are founded in the conceptual framework proposed in Figure 3 recognizing how the fluvial environment meets the biological resource needs of fish, specifically for the following strategies: feeding, resting, spawning, escape from predation, temperature refuge, and flow refuge; and organized by streamflow stage and seasonal period. Key background information on these elements and existing mesohabitat classification schemes are summarized in the following subsections.

\subsection{Mesohabitat Units at Low-Flow Stages}

Mesohabitat units at the low-flow stage represent bed topography elements characterized by geomorphological and hydraulic characteristics, relative flow depths, and relations to trait strategies (Table 2). Based on formative geomorphic processes, mesohabitat units were grouped into erosional and depositional subcategories [79]. Formative geomorphic processes refer to the aggradation and degradation of bed sediments during high-flow discharges that create and maintain the complexity of the channel bed morphology, termed herein as bed topography elements [74,75]. Hydraulic characteristics associated with the different morphologies were based on 3D acoustic Doppler velocimeter (ADV) measurements [147,262]. Fish mesohabitat use was determined by PAEDs specifically designed to collect fish within exact unit boundaries and without fright bias [93,96]. Collectively, the classification scheme was based on field observations of geomorphic structure, hydraulics, and fish spatial occupancies; and published studies on geomorphic processes and species trait-based analyses [32].

Mesohabitat units, categorized by the formative geomorphic process as erosion, include a main channel pool and a scour pool (Table 2). The main channel pool is subdivided longitudinally into three hydraulic regions as the front, mid, and rear areas [79]. These pool area subdivisions are also relevant to pool-riffle maintenance processes as described above [154-157]. Geomorphologically, a main channel pool is differentiated from a scour pool in that its length is greater than its channel width. In contrast, a scour pool is smaller in size with its length less than the channel width. Its minimum length, width and depth are about $1.5 \mathrm{~m}, 1.2 \mathrm{~m}$. and $0.25 \mathrm{~m}$, respectively [79]. The pool front unit represents the entrance slope to a local topographic low along the streambed, as observed by the downward-directed bed slope orientated with flow. The pool mid unit is the level bed area represented as a local topographic low. The pool-rear unit represents the exit slope, as observed by the upward-directed bed slope orientated with flow. 
Table 2. Geomorphological and hydraulic characteristics of low-flow mesohabitat units in low-gradient streams of the US Midwest. Classification characteristics adapted from [79]; and example ecological traits/strategies based on species occupancy [32].

\begin{tabular}{|c|c|c|c|}
\hline \multicolumn{4}{|c|}{ Formative Geomorphic Process: Erosion } \\
\hline Mesohabitat Unit & Geomorphic Characteristics & Hydraulic/Flow Depth Characteristics & Ecological Trait/Strategies \\
\hline Pool Front & $\begin{array}{l}\text { Entrance slope to a pool; } \\
\text { downward-directed bed slope } \\
\text { oriented with flow. }\end{array}$ & $\begin{array}{l}\text { Flow acceleration, and strong outward velocities in meanders; } \\
\text { relatively high turbulence }[147,154,159] \text {. Moderately deep }(0.25-0.35 \mathrm{~m}) \text {. }\end{array}$ & Feeding by insectivores \\
\hline Pool Mid & $\begin{array}{l}\text { Topographic low along streambed; } \\
\text { level bed. }\end{array}$ & $\begin{array}{l}\text { Transition from flow acceleration to deceleration flow, and strong } \\
\text { secondary circulation; submergence of high-velocity core; moderate } \\
\text { turbulence }[136,147,150,154,159] \text {. Deep }(0.4-1.2 \mathrm{~m}) \text {. }\end{array}$ & $\begin{array}{l}\text { Feeding by piscivores and } \\
\text { topminnows. Broadcast spawners. }\end{array}$ \\
\hline Pool Rear & $\begin{array}{l}\text { Exit slope to a pool; upward-directed } \\
\text { bed slope oriented with flow. }\end{array}$ & $\begin{array}{l}\text { Flow deceleration, and diminishing secondary circulation; relatively low } \\
\text { turbulence }[147,154,159] \text {. Moderately deep }(0.25 \mathrm{~m}) \text {. }\end{array}$ & Gravel nesting spawners. \\
\hline Local Scour Pool & $\begin{array}{l}\text { Small area of topographic low in bed; } \\
\text { length smaller than channel width. }\end{array}$ & $\begin{array}{l}\text { Local flow acceleration due to deflection and constriction of flow } \\
\text { field [63,261,263-265]. Moderately deep }(0.3 \mathrm{~m}) \text {. }\end{array}$ & Feeding by omnivores. \\
\hline \multicolumn{4}{|c|}{ Formative Geomorphic Process: Deposition } \\
\hline Mesohabitat Unit & Geomorphic Characteristics & Hydraulic/Flow Depth Characteristics & Ecological Trait/Strategies \\
\hline Glide & $\begin{array}{l}\text { Intermediate bed topographic } \\
\text { elevation; level and uniform bed. }\end{array}$ & $\begin{array}{l}\text { Uniform downstream velocity vectors; minimal secondary } \\
\text { circulation }[63,212,246,251] \text {. Moderately Shallow }(0.25 \mathrm{~m}) \text {. }\end{array}$ & $\begin{array}{l}\text { Feeding by omnivores, herbivores. } \\
\text { Spawning by nest builders, other }\end{array}$ \\
\hline $\begin{array}{l}\text { Riffle without } \\
\text { Raceway }\end{array}$ & $\begin{array}{l}\text { Topographic intermediate to high } \\
\text { along streambed; lateral bed } \\
\text { morphology diversity. }\end{array}$ & $\begin{array}{l}\text { Downstream velocities accelerate from increasing bed slope, weak } \\
\text { surface-divergent secondary circulation; relatively moderate } \\
\text { turbulence }[63,136,150] \text {. Moderately shallow }(0.20 \mathrm{~m}) \text {. }\end{array}$ & $\begin{array}{l}\text { Feeding by generalist and } \\
\text { benthic insectivores. }\end{array}$ \\
\hline Riffle with Raceway & $\begin{array}{l}\text { Topographic high along streambed; } \\
\text { sinuous flow path through alluvium } \\
\text { during low flow; diverse bed } \\
\text { morphology with small depressions. }\end{array}$ & $\begin{array}{l}\text { Downstream velocities accelerate from increasing bed slope, weak } \\
\text { surface-divergent secondary circulation relatively moderate } \\
\text { turbulence }[63,136,147] . \text { Very shallow with deep "pockets" }(0.1-0.3 \mathrm{~m}) \text {. }\end{array}$ & $\begin{array}{l}\text { Feeding by omnivores and } \\
\text { herbivore. Spawners by egg } \\
\text { adherence to gravel; darter resting }\end{array}$ \\
\hline Submerged Bar & $\begin{array}{l}\text { Lateral topographic high adjacent to } \\
\text { pool, and extending into riffle } \\
\text { structure. }\end{array}$ & $\begin{array}{l}\text { Low velocities due to shoaling and lateral deflection of flow by the point } \\
\text { bar; flow separation adjacent to or in lee of the point bar }[136,147,149] \text {. } \\
\text { Shallow }(0.15 \mathrm{~m}) \text {. }\end{array}$ & $\begin{array}{l}\text { Evasion from predation by } \\
\text { cyprinid young-of-the-year }\end{array}$ \\
\hline $\begin{array}{l}\text { Lateral Area in Lee of } \\
\text { an Obstruction }\end{array}$ & $\begin{array}{l}\text { Intermediate topographic elevation } \\
\text { laterally positioned behind instream } \\
\text { or bank structural element; area in } \\
\text { lee of obstruction. }\end{array}$ & $\begin{array}{l}\text { Separated, stagnant water or recirculating flow in lee of } \\
\text { obstacle }[251,261,263] \text {. Shallow }(0.15 \mathrm{~m}) \text {. }\end{array}$ & $\begin{array}{l}\text { Evasion-escape from predators; } \\
\text { resting; spawners by egg adherence } \\
\text { to vegetation }\end{array}$ \\
\hline
\end{tabular}


Distinct flow structures occur through the three areas of a main channel pool, particularly in pools associated with a meandering channel in which the flow field is influenced by curvature [136,147,163,266-269]. Convective acceleration of the flow occurs at the front of the pool, with flow in meanders strongly directed towards the outer bend [154]. In the deeper mid-area of the pool, the flow structure begins to transition from convective acceleration to deceleration generating strong secondary circulation. Convective deceleration occurs at the exit slope of the pool, along with diminishing secondary circulation. Turbulence, as turbulent kinetic energy (TKE), is greatest in the front of the pool and weakens through the pool areas as secondary circulation redistributes energy and momentum $[147,259,264]$. Similar hydraulic conditions occur through the pools in low-sinuosity channels where the main channel flow is deflected by lateral structures [263]. The scour pool unit hydraulically is similar to that of pool front unit where convective acceleration generates velocities directed downward towards the bed [269]. They differ in that the small size of the hydraulic units likely limits development of secondary circulation. In-stream structures control the location of scour pools, and in prairie streams they include sod blocks from bank failures, LWD, exposed tree root wads, rock, and human-deposited debris.

Mesohabitat units, categorized by the formative geomorphic process of deposition, include two types of riffles, a glide, a bar platform, and a lateral area in the lee of an obstruction (LAT) unit (Table 2). These units are generally considered as topographic highs on the streambed compared to the pool-type units $[63,74,79,128,262]$. Riffle units were observed as those with and without a raceway. A raceway consisted of a sinuous thalweg forming a low-flow channel deeper than very shallow or non-wetted, exposed lateral and mid-channel bars (Figure 4). Small, deep pockets of water sometimes form in the bed along the thalweg $(0.15 \mathrm{~m}$ depth), though typically the water depth was very shallow over gravel-sand mix $(<0.1 \mathrm{~m})$. A riffle with a raceway typically had a unit length in the order of 3 to 10 times the active channel width. In contrast to a riffle without a raceway, unit lengths were approximately equal to the active channel width, and laterally-deposited sediment was submerged during baseflow. Water depth in riffle units without a raceway was moderately shallow and comparable to a glide at the deepest side laterally, ranging in depth from 0.17 to $0.30 \mathrm{~m}$. Glides have variable unit lengths with uniform bed topography. Bar platforms consisted of lateral sediment deposits including point bars along the inner bank of meanders, and alternative bars in straight channels. LAT habitat units include areas behind bank failures, and lateral margin areas where the channel abruptly expands including floodplain sloughs and early stages of concave-bank bench planform development [32].

Flow structures differ among the depositional habitat units and consist of either main channel hydraulic patterns in riffles and glides, or hydraulically separated, low-velocity areas of a bar platform and a LAT unit $[79,136]$. This classification scheme recognized the fluvial dynamics of a geomorphic bar unit by incorporating the Bar Unit Concept [36]. As a single geomorphic unit consisting of pool-riffle-bar morphology, the fluvial dynamics is characterized by a 3D convergent-divergent helical flow pattern $[147,149,150,153]$. In riffles during low flow, downstream-directed velocities accelerate slightly from the reduced water depth, and turbulence is moderate in relative comparison to high TKE observed in the front of pool $[152,156]$. Over bar platforms, low velocities are due to shoaling and lateral deflection of flow by the point or alternate bar with possible flow separation adjacent to or in the lee of the bar $[136,147,149,154,157]$. Glides are assumed to represent uniformly-directed downstream velocities with minimal secondary circulation $[63,213]$. The LAT habitat unit occurs downstream of a structural constriction to flow, and lies laterally adjacent to a scour pool formed by the structure [160]. Hydraulically during baseflow, this lateral habitat unit consists of separated, stagnant water or possibly low-velocity recirculating water in some locations (Figure 4).

Within the framework of ecological traits and strategies as shown in Figure 3, relationships between general trait expressions and mesohabitat unit type are demonstrated in Table 2 . These relationships were based on statistically distinct patterns of fish occupancy and a trait-based analysis [63,79]. The greatest richness and density occurred during the summer and fall periods, with a total of 23 species and average unit densities ranging from 4.9 to 218.6 fish per $100 \mathrm{~m}^{2}$. Others found the 
same seasonal patterns of use where feeding, resting, evasion from predation, and spawning were the dominant trait strategies [172,178,179,193,194,197,198,201,203,214-216]. Schwartz and Herricks (2008) [79] found that feeding strategy could be summarized as: insectivores mainly occupying the pool-front unit, omnivores in the scour pool unit, piscivores in the pool-mid unit, and herbivores in the glide and riffle with raceway unit. Feeding strategy was weakly expressed in the other unit types. Evasion and escape from predation were observed in the LAT unit and submerged point bar. Resting behavior was dependent on body morphology with centrarchids in the LAT unit, and darters and some cyprinids in the riffle with raceway unit. Spawning behavior was highly varied and different strategies related to the unit hydrogeomorphic conditions. For example, broadcast spawners would generally be found in pool-mid units, whereas gravel nest spawners will be found in the pool-rear unit, riffle, and glide units. More focused research is needed to generate direct spawning trait-habitat relationships, but general information is available from literature and trait databases [179,245]. During the harsh winter months, most fish species found refuge in the deep pool-mid units, through the submerged bar and riffle with raceway units were used to a greater extent compared to the summer-fall season [32].

a)
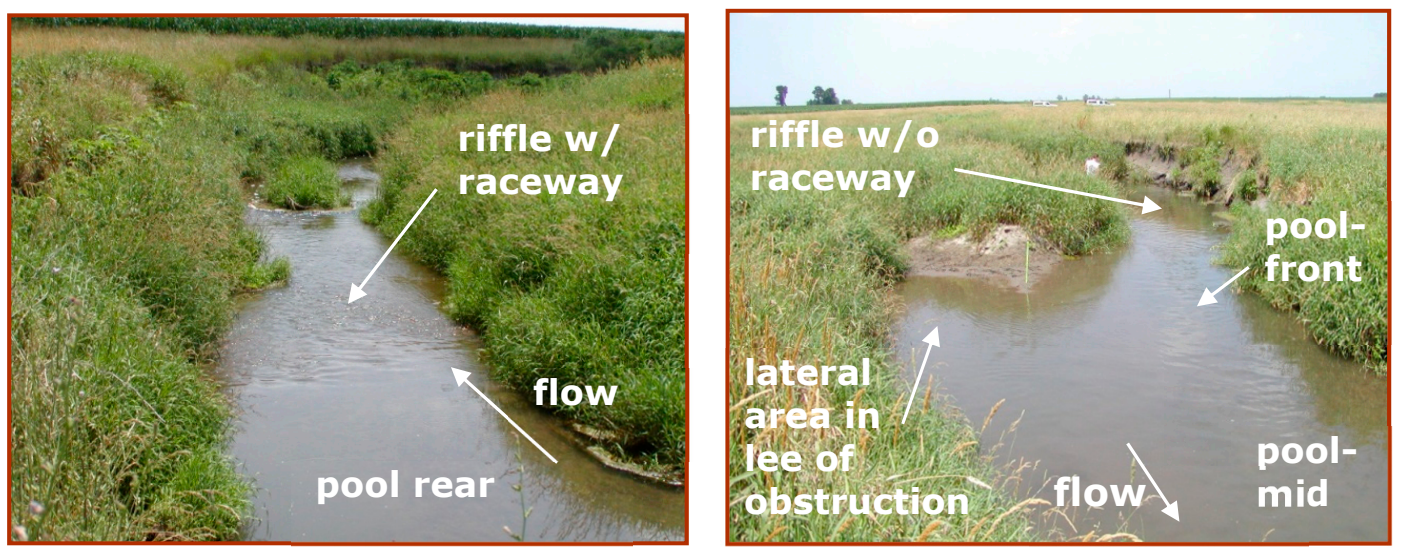

b)
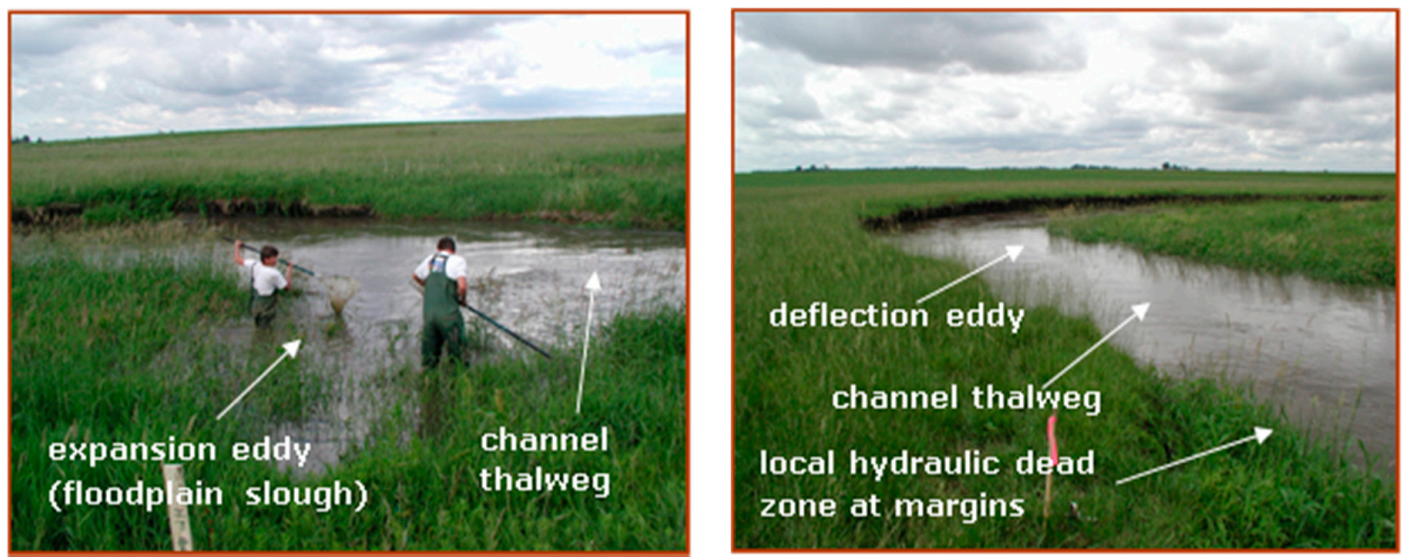

Figure 4. Photo showing examples of mesohabitat units during (a) low-flow and (b) high-flow stages in the Embarras River headwaters (third-order stream with $476 \mathrm{~km}^{2}$ drainage basin); located approximately $15 \mathrm{~km}$ south of Urbana, IL, USA.

\subsection{Mesohabitat Units at High-Flow Stages}

Mesohabitats units at high-flow stages represent different hydrodynamic conditions as channel areas of high- and low-velocities (Table 3). These areas develop as flows interact with the channel morphology including planform sinuosity, floodplain-channel morphology, bed topography and large roughness elements influencing the 3D hydraulic characteristics $[71,128,135,137,253,262,270-273]$. 
Three hydraulic categories were used to classify high-flow mesohabitat units; they include: (1) the high-velocity corridor within the active channel; (2) low-velocity areas along the active channel margins and (3) low-velocity areas at the channel-floodplain interface [253]. In the main active channel area, topography and hydraulic zones of separated flow direct a high-velocity sinuous corridor. During flood flows, stage height determines what high-flow mesohabitat units are available for fish occupancy. Velocities in the high-velocity corridor ranged from 0.56 to $1.49 \mathrm{~m} \cdot \mathrm{s}^{-1}$, and they were mostly zero in the low-velocity areas though velocities between 0.03 and $0.08 \mathrm{~m} \cdot \mathrm{s}^{-1}$ were measured at some units [253].

Within the active channel during high flows, the "high-velocity corridor" habitat unit follows the channel thawleg, the longitudinal path of maximum depth (Table 3; Figure 4). The downstream-directed velocities are swift within this habitat unit creating a harsh environmental for many fish species [181-183]. Spatially, this high-flow habitat unit overlies with the bed topography elements at the low-flow stages consisting of following habitat units: the four pool units, scour pool, the two riffles, and glide (Figure 5). Along the thawleg and high-velocity corridor, pools and riffles are maintained by the geomorphic processes described above per the velocity reversal hypothesis and flow acceleration-deceleration concept $[141,142,156,159]$.
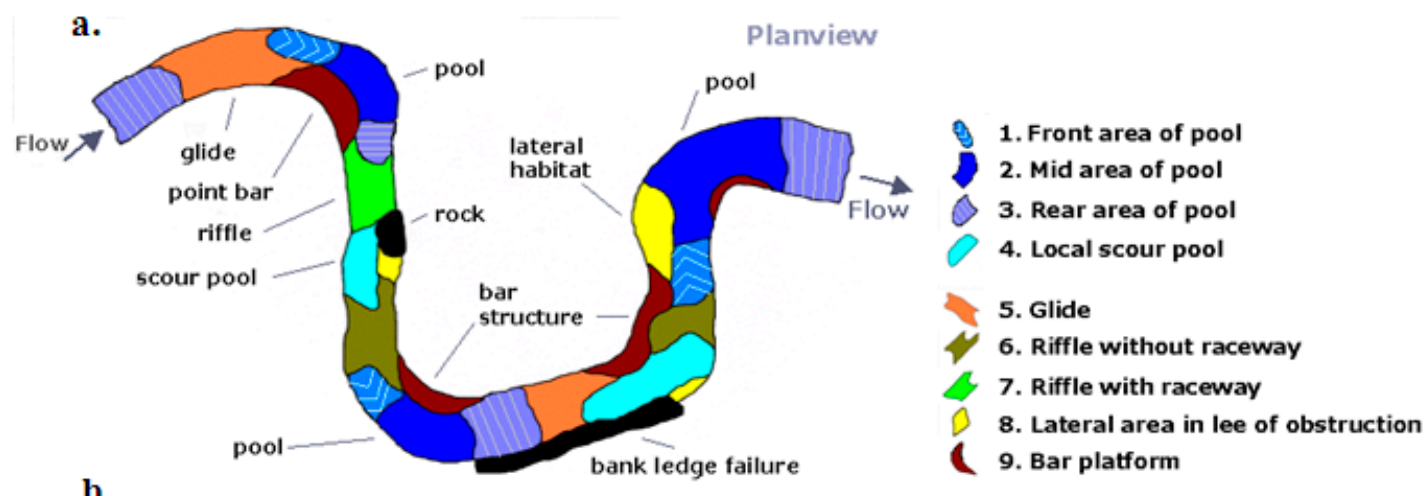

b.
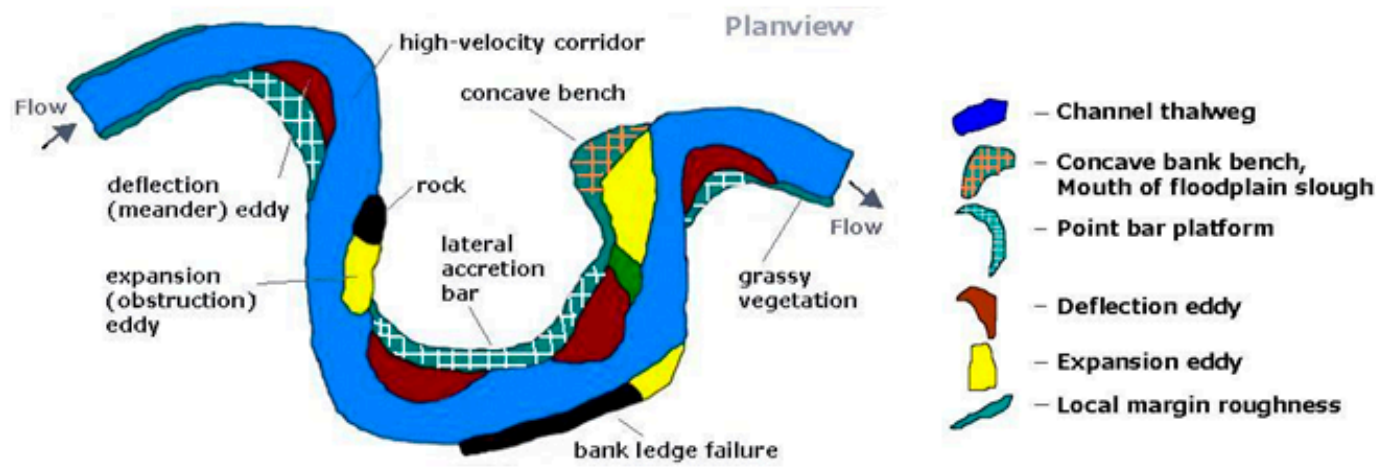

Figure 5. Illustration of a spatial arrangement of mesohabitat units at: (a) baseflow stage, changing to units; and (b) high-flow stage for the same channel reach. 
Table 3. Geomorphological and hydraulic characteristics of fluvial habitat units during high-flow stages in small, low-gradient streams in the Midwest, USA. Table modified from [253].

\begin{tabular}{|c|c|c|c|}
\hline Habitat Unit & Geomorphological Characteristics & Topographic Elevation & Hydraulic Characteristics \\
\hline \multicolumn{4}{|c|}{ Hydrodynamic Condition: High-velocity corridor within the main channel } \\
\hline Channel Thalweg & $\begin{array}{l}\text { Path of maximum depth and velocity within the } \\
\text { channel; often shifts laterally across channel in } \\
\text { conjunction with pool-riffle-bar morphology [71] }\end{array}$ & $\begin{array}{l}\text { Lowest bed elevation in active } \\
\text { channel }[71,156]\end{array}$ & $\begin{array}{l}\text { Convergent-divergent flow pattern associated } \\
\text { with pool-riffle-bar morphology; helical flow in } \\
\text { pools; strong downstream velocities; high shear } \\
\text { stress in pools }[71,136,147]\end{array}$ \\
\hline \multicolumn{4}{|c|}{ Hydrodynamic Condition: Low-velocity areas along active channel margins } \\
\hline Deflection Eddy & $\begin{array}{l}\text { Strong topographic deflection of flow laterally by } \\
\text { elevated point-bar head, especially in sharp bends, } \\
\text { resulting in an elongated zone of flow separation } \\
\text { along inner bank }[147,263] \text {. }\end{array}$ & $\begin{array}{l}\text { Intermediate bed elevation at margin } \\
\text { of active channel along interface of } \\
\text { point-bar face and platform; inundated } \\
\text { with flow. }\end{array}$ & Separated, recirculating flow $[136,147,150]$ \\
\hline Expansion Eddy & $\begin{array}{l}\text { Abrupt expansions of channel width at local } \\
\text { re-entrants associated with remnant channels } \\
\text { (floodplain sloughs) [137] or early stages of concave } \\
\text { bank bench development in meandering } \\
\text { channels [134], local bank ledge failures or other } \\
\text { large structures that create local lateral channel } \\
\text { constrictions [263,264]. }\end{array}$ & $\begin{array}{l}\text { Local topographic low along channel } \\
\text { bank, producing intermediate bed } \\
\text { elevation within active channel; } \\
\text { inundated above baseflow }[270,273] \text {. }\end{array}$ & $\begin{array}{l}\text { Separated, recirculating flow within expansion } \\
\text { zone }[136,147,150] .\end{array}$ \\
\hline \multicolumn{4}{|c|}{ Hydrodynamic Condition: Low-velocity areas at channel-floodplain transition } \\
\hline $\begin{array}{l}\text { Remnant Point-bar } \\
\text { Platforms, Vegetated }\end{array}$ & $\begin{array}{l}\text { Grassy, vegetated zones on surface of point-bar } \\
\text { platform along inner (convex) bank of meander } \\
\text { bends [71]. }\end{array}$ & $\begin{array}{l}\text { Elevated surface above active channel; } \\
\text { inundated at bankfull or overbank } \\
\text { flows [273]. }\end{array}$ & $\begin{array}{l}\text { Low velocities or recirculating flow from high } \\
\text { hydraulic roughness during bankflow flow [264]. }\end{array}$ \\
\hline Concave-bank Bench & $\begin{array}{l}\text { Crescent-shaped depositional area at location } \\
\text { corresponding to upstream limb of concave bank in } \\
\text { the next bend downstream [134] bench becomes } \\
\text { vegetated with grass. }\end{array}$ & $\begin{array}{l}\text { Elevated surface about active channel; } \\
\text { flood inundation only during bankfull } \\
\text { or overbank flows }[134,135] \text {. }\end{array}$ & $\begin{array}{l}\text { Separated, recirculating flow resulting from } \\
\text { enlargement of expansion eddy during bankflow } \\
\text { flow }[134,270] \text {. }\end{array}$ \\
\hline $\begin{array}{l}\text { Remnant channels; } \\
\text { floodplain slough } \\
\text { mouth }\end{array}$ & $\begin{array}{l}\text { Remnant channels lateral to active channel; } \\
\text { gradually slope towards at re-entrants locations at } \\
\text { the mouth of floodplain sloughs }[137,270,271] \text {. }\end{array}$ & $\begin{array}{l}\text { Elevated surface about active channel; } \\
\text { flood inundation only during bankfull } \\
\text { or overbank flows }[135,137] \text {. }\end{array}$ & $\begin{array}{l}\text { Separated, recirculating flow resulting from } \\
\text { enlargement of expansion eddy during bankflow } \\
\text { flow [270]. }\end{array}$ \\
\hline
\end{tabular}


When floodwaters rise above baseflow, low-velocity areas form along the channel margins, including a "local hydraulic dead zone at margins" unit parallel to the bank with vegetation, and hydraulic recirculation zones classified as either a deflection or expansion eddy (Table 3; Figure 4). Deflection eddies occur in meanders where a strong lateral deflection by the point bar, along with abrupt changes in channel direction create a zone of flow separation and large recirculation area in the lee of the point bar $[147,149]$. Helical flows in the downstream direction also play a role in this process by redistributing momentum across the channel, and influence overall 3D velocities and turbulence patterns $[147,259,264]$. Expansion eddies occur where accelerated flow due to a constricted cross-sectional area is followed by an abrupt lateral expansion of channel morphology forming recirculating fluid $[263,266]$. In low-gradient streams, large bank ledge failures can laterally impinge the flow field forming a hydraulic recirculation zone in the lee of the obstruction. Channel expansions also occur at planform morphological features, i.e., mouth of a remnant channel [137].

Morphological surfaces that become inundated during very high flows nearing or exceeding top of bank provide short-term, but essential habitat for fish refugia [32]. Three fluvial habitat units are classified; they are remnant point bar platforms, concave-bank benches, and old remnant channels that lead to the mouth of floodplain sloughs (Table 3). These habitat units are shallow, low-velocity patches with emergent grass vegetation less than a meter in depth. Remnant point bar units are a lateral extension of the in-channel bar structure where the deflection eddy occurs. Knighton (1998) [71] refers to them as lateral accretion bars, where sediment deposition vertically builds the geomorphic surface as the channel bend migrates in the floodplain. Concave-bank benches differ from point bar development in that they are not laterally accreting geomorphic platforms [134]. Rather, concave-bank benches form through the deposition of fine sediments in an over widened channel bend immediately upstream of the point of maximum curvature in a meander. Over-widening of the channel at this location is facilitated by rapid erosion of the upstream concave bank, and during high flows forms an expansion eddy unit in the active channel. In general, meandering processes over time leave remnant channels at elevations above the active channel forming local geomorphic platforms at the transition between the channel and the floodplain $[135,137,270,271]$. These remnant channels form a slough feature at the exit of a former active channel. Floodplain locations of sloughs are areas where the channel width expands abruptly; forming expansion eddies at the active channel margin during high flows [253].

Ecologically, fish species differentially use high-flow habitats but the strategy is singular finding refugia from swift flows in lateral hydraulic recirculation zones [253]. During the flood period, half to bankfull stages, fish densities were greatest in the deflection and expansion eddy units. Also, fish densities and biomass were greater in the deflection eddies than the expansion eddies, averaging $3.33 \mathrm{fish} / \mathrm{m}^{2}$ and $6.87 \mathrm{~g} / \mathrm{m}^{2}$; and $1.13 \mathrm{fish} / \mathrm{m}^{2}$ and $2.57 \mathrm{~g} / \mathrm{m}^{2}$; respectively. Schwartz and Herricks (2005) [253] reported that average TKE was greater in the deflection eddy $\left(52.3 \mathrm{~cm}^{2} \cdot \mathrm{s}^{-2}\right)$ than the expansion eddy $\left(20.0 \mathrm{~cm}^{2} \cdot \mathrm{s}^{-2}\right)$, which poses an interesting question of whether fish during flood flows respond to this hydraulic property. Overall, fish assemblages significantly differed among the different high-flow habitat units, providing evidence to their ecological relevance for use in stream restoration design. Literature indicates some species exploit food resources on the episodic submerged floodplain $[52,184,188,223]$. In general, the importance of flood refugia has been recognized in stream restoration for agricultural Midwest streams with two-stage cross-sectional designs [274-276]. Further research is needed to enhance of understanding of trait expression associated with these high-flow mesohabitat units.

\section{Ecohydraulic-Based Stream Restoration: Proposed Application}

Advancing stream restoration design with ecological performance outcomes requires a pre-design integration of fluvial geomorphic, hydraulic, and ecological principles incorporated into an applicable mesohabitat classification scheme (Figure 1b). Classification schemes should be unique to an ecoregion and watershed longitudinal position (headwater to large river segments). Most restoration projects are implemented in small streams at the reach-scale (second to third stream order) reconfiguring bedforms as 
mesohabitat structure $[2,4,44,277,278]$. As this review suggests the ecological component to restoration design may be advanced through the use of mesohabitat classification that reflects trait-habitat relationships for key biological resource needs, utilizing a functional traits database (Figure 3). Use of fish species traits is applicable for restoration design because trait-habitat relationships scale to constructible habitat patches as geomorphic bedforms and elevated channel-floodplain surfaces.

A proposed restoration design strategy is illustrated in Figure 6 that applies a multi-stage ecohydraulic mesohabitat classification scheme developed specifically for an ecoregion. This review demonstrated a classification scheme for the prairie Midwest (Ecoregion 54), thus would not solely be applicable in other ecoregions. For example in the Pacific Northwest Coast Range (Ecoregion 1), side channel habitat for winter rearing is dominant mesohabitat, in addition to cascades and other high-gradient type units are utilized by various trout species for feeding $[65,279]$. However, some units will be more ubiquitous such as the pool-front, -mid, and -rear units, and glides.

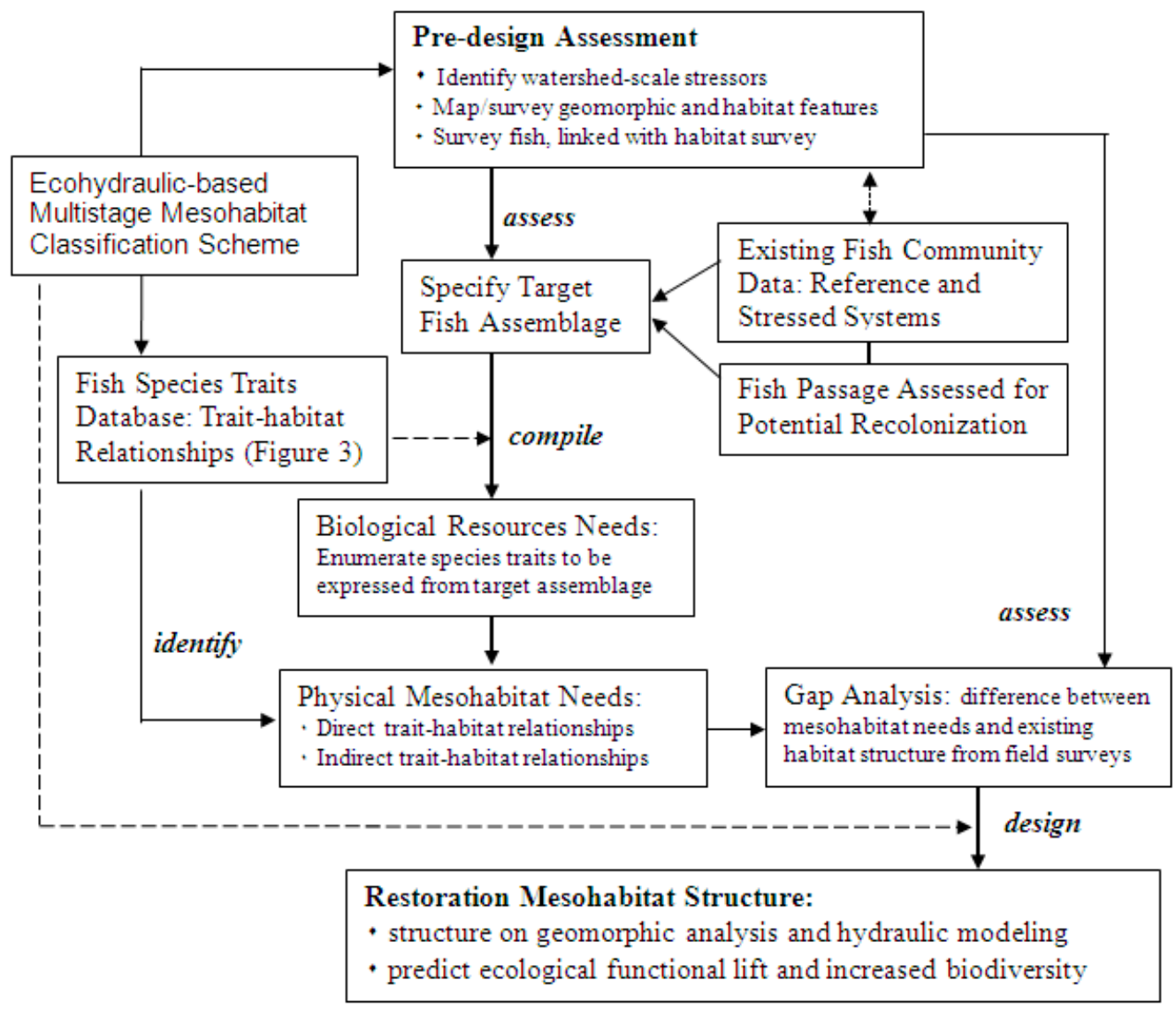

Figure 6. Proposed design protocols for multi-stage ecohydraulic stream restoration using an ecoregion-specific mesohabitat classification scheme and species functional traits.

The stream restoration design strategy as shown in Figure 6 begins with a pre-design assessment consisting of a watershed-scale stressor analysis (Figure 2), standard fish surveys [280], and mesohabitat surveys mapping habitat units in sequence [63-65]. Implementation of a functional traits analysis with a mesohabitat classification scheme first requires a target fish community [108,111]. By identifying the target species, traits and strategies can be summarized from available databases [113,245]. The suggested target community relies on professional judgement, which is supported by fish surveys from both local reference conditions and ecologically impaired streams, in addition to recolonization potential of different species $[211,237,281,282]$. After the target fish assemblage (community) has been identified, procedures utilizing species functional traits for restoration design are suggested as follow: 
(1) Enumerate the functional traits expressed per fish species in the target community, summarizing the frequency of traits expressed because various traits will be expressed by multiple species in the target assemblage;

(2) Summarize physical habitat needs based on the enumerated functional traits of the target assemblage, which constitutes the functional traits analysis (Figure 3); it should be noted that habitat needs could be direct or indirect, where a direct need is the explicit space occupancy for a specified trait expression (e.g., mid-pool resting) and indirect need is space used by another organism needed for a target species, for example pool-front feeding with the food source (benthic macroinvertebrates) generated in the adjacent upstream riffle;

(3) Compile data from field surveys of stream habitat, and summarize the proportion of each mesohabitat unit types per proposed restoration reach; this includes both low- and high-flow units $[19,63,64]$;

(4) Compare the existing mesohabitat units from the stream surveys with a set of habitat units derived from the functional traits analysis, identifying any departures between the two (gap analysis); and

(5) Of the mesohabitat unit types found to be limited, summarize measures of physical structural heterogeneity and complexity from field surveys, and design the restored habitat based on trait-habitat relationships, and geomorphic and hydraulic principles.

This trait-based mesohabitat procedure for stream restoration assumes degraded channel morphology can be modified by adjusting planform and slope, cross-sectional area, or adding roughness and grade control structures to achieve a channel near a geomorphic 'dynamic' equilibrium state. In addition, the procedure assumes there is a regional species pool for recolonization of species based on the proposed target fish assemblage, which accounts for the existing multiple stressors in the watershed. It accomplishes the overall goal where mesohabitat units represent unique process-based relationships of geomorphic maintenance and ecosystem function.

\section{Conclusions}

Ecological restoration of streams is quite challenging, particularly in human-dominated watersheds with multiple stressors. There is a need to advance our current science-based restoration tools in order to better integrate ecological information into the planning and design phases of stream restoration projects. In addition, there is a growing need in the US to quantify ecological outcomes in order to meet compensatory mitigation requirements, referred to as "functional lift" [83]. The European Union has similar goals as defined in the 2000 Water Framework Directive Framework, whereby ecological condition is to be restored and quantified through assessments [283]. The proposed application of an ecohydraulic-based design approach is suggested for the stream restoration practice, which utilize an ecoregion-specific mesohabitat classification scheme and a 2D hydraulic habitat model. Multidimensional hydrodynamic models can be effectively integrated with ecological design [99]. These models can predict flow patterns at multiple stages, and a mesohabitat template can be overlaid and enumerated with the design reach. Analysis of model outcomes can include summing the potential traits strategies that may be expressed based the mesohabitat classification scheme as described above in Section 6. The overall aim with the use of these tools is to improve ecological outcomes of channel restoration projects.

The key points of this review suggesting the use of multi-stage ecohydraulic-based mesohabitat classification schemes to improve stream restoration design practices by integrating geomorphic, hydraulic and ecological principles are summarized as follow:

(1) physical habitat space is specifically linked with species functional traits so that mesohabitat units form the basic "building blocks" for stream restoration design, recognizing that habitat unit use shifts with season and flow stage governed by life histories and trait strategies; 
(2) high-flow refugia must be considered in restoration design, characterized by elevated geomorphic surfaces at the channel-floodplain interface;

(3) mesohabitat units must be associated with mesoscale 3D hydraulic and turbulence patterns that relate to trait strategies, i.e., feeding and spawning positions; and

(4) the restoration design process must recognize the self-maintenance geomorphic processes for both low- and high-flow mesohabitats, the spatial-process linkages for reach-scale bed topography, bank, and elevated floodplain-channel geomorphic surfaces.

The classification scheme presented in this review was developed for Midwest prairie streams, and used as a demonstration of how these key principles can be considered to other ecoregions. It is acknowledged that the design procedures described here within need further development, including fish preferences to new, uniquely defined mesohabitat unit delineations, and spatial considerations associated to unit juxtaposition. Overall, these procedures applying species functional traits appear promising to advance of practice of ecological restoration of streams where enhanced mesohabitat structure specifically meets the biological needs of a target biota assemblage.

Acknowledgments: The research was supported as part of the project "Development of an Integrated Scientific and Technological Framework for Stream Naturalization" Grant 98-NCERQA-MI, funded by the Water and Watersheds Program of the United States Environmental Protection Agency. Funds supporting this effort also included the US Geological Survey 104b Program administered by the Tennessee Water Resources Research Center. The author is very grateful for the academic support provided by Edwin Herricks, Bruce Rhoads and Marcelo Garcia at the University of Illinois-Champaign/Urbana during development of the author's Ph.D. dissertation. Also, the author thanks the anonymous reviewers for their helpful suggestions improving the manuscript.

Conflicts of Interest: The author declares no conflict of interest.

\section{References}

1. Alexander, G.G.; Allan, J.D. Stream restoration in the upper Midwest, U.S.A. Restor. Ecol. 2006, 14, 595-604. [CrossRef]

2. Bernhardt, E.S.; Sudduth, E.B.; Palmer, M.A.; Allan, J.D.; Meyer, J.L.; Alexander, G.; Follstad Shah, J.; Hassett, B.; Jenkinson, R.; Lave, R.; et al. Restoring rivers one reach at a time: Results from a survey of U.S. river restoration practitioners. Restor. Ecol. 2007, 15, 82-93. [CrossRef]

3. Lave, R. Field and Streams: Stream Restoration, Neoliberalism and the Future of Environmental Science; The University of Georgia Press: Athens, GA, USA, 2012; p. 170.

4. Palmer, M.A.; Hondula, K.L.; Koch, B.J. Ecological restoration of stream and rivers: Shifting strategies and shifting goals. Annu. Rev. Ecol. Evol. Syst. 2014, 45, 247-269. [CrossRef]

5. Bernhardt, E.S.; Palmer, M.A.; Allan, J.D.; Alexander, G.; Barnas, K.; Brooks, S.; Carr, J.; Clayton, S.; Dahm, C.; Follstad-Shah, J.; et al. Synthesizing U.S. river restoration efforts. Science 2005, 308, 636-637. [CrossRef] [PubMed]

6. Rosgen, D. Applied Stream Geomorphology; Wildland Hydrology: Pagoda Springs, CO, USA, 1996.

7. Hey, R.D. Fluvial geomorphological methodology for natural stable channel design. J. Am. Water Resour. Assoc. 2006, 42, 357-374. [CrossRef]

8. Jenkinson, R.G.; Barnas, K.A.; Braatne, J.H.; Bernhardt, E.S.; Palmer, M.A.; Allan, J.D.; The National River Restoration Science Synthesis. Stream restoration databases and case studies: A guide to information resources and their utility in advancing the science and practice of restoration. Restor. Ecol. 2006, 14, 177-186. [CrossRef]

9. Rosgen, D.L. Natural channel design: Fundamental concepts, assumptions, and methods. In Stream Restoration in Dynamic Fluvial Systems: Scientific Approaches, Analysis, and Tools; Simon, A., Bennett, S.J., Castro, J.M., Eds.; Geophysical Monograph Series 194; American Geophysical Union: Washington, DC, USA, 2011; pp. 69-94.

10. Rosgen, D.L. Rosgen geomorphic channel design. In Part 654 Stream Restoration Design National Engineering Handbook; U.S.D.A. National Resources Conservation Service: Washington, DC, USA, 2007; pp. 1-76.

11. Shields, F.D.; Copeland, R.R.; Klingeman, P.C.; Doyle, M.W.; Simon, A. Design for Stream Restoration. ASCE J. Hydraul. Eng. 2003, 129, 575-584. [CrossRef] 
12. Copeland, R.R.; McComas, D.N.; Thorne, C.R.; Soar, P.J.; Jonas, M.M.; Fripp, J.B. Hydraulic Design of Stream Restoration Projects; ERDC/CHL TR-01-28; U.S. Army Corps of Engineers: Washington, DC, USA, 2001; p. 109.

13. Downs, P.W.; Thorne, C.R. Rehabilitation of a lowland river: Reconciling flood defence with habitat diversity and geomorphological sustainability. J. Environ. Manag. 2000, 58, 249-268. [CrossRef]

14. Niezgoda, S.L.; Johnson, P.A. Modeling the Long Term Impacts of Using Rigid Structures in Stream Channel Restoration. J. Am. Water Resour. Assoc. 2006, 42, 1597-1613. [CrossRef]

15. Miller, J.R.; Kochel, R.C. Assessment of channel dynamics, in-stream structures and post-project channel adjustments in North Carolina and its implications to effective stream restoration. Environ. Earth Sci. 2010, 59, 1681-1692. [CrossRef]

16. Buchanan, B.P.; Nagle, G.N.; Walter, M.T. Long-term monitoring of a stream restoration project in central New York. River Res. Appl. 2014, 30, 245-258. [CrossRef]

17. Kondolf, G.M. Five elements for effective evaluation of stream restoration. Restor. Ecol. 1995, 3, 133-136. [CrossRef]

18. Aarts, B.G.W.; Van Den Brink, F.W.B.; Nienhuis, P.H. Habitat loss as the main cause of the slow recovery of fish faunas of regulated large rivers in Europe: The transversal floodplain gradient. River Res. Appl. 2004, 20, 3-23. [CrossRef]

19. Schwartz, J.S.; Herricks, E.E. Evaluation of pool-riffle naturalization structures on habitat complexity and the fish community in an urban Illinois stream. River Res. Appl. 2007, 23, 451-466. [CrossRef]

20. Tullos, D.D.; Penrose, D.L.; Jennings, G.D.; Cope, W.G. Analysis of functional traits in reconfigured channels: Implications for the bioassessment and disturbance of river restoration. J. N. Am. Benthol. Soc. 2009, 28, 80-92. [CrossRef]

21. Palmer, M.A.; Menninger, H.L.; Bernhardt, E. River restoration, habitat heterogeneity and biodiversity: A failure of theory or practice? Freshw. Biol. 2010, 55, 205-222. [CrossRef]

22. Haase, P.; Hering, D.; Jahnig, S.C.; Lorenz, A.W.; Sundermann, A. The impact of hydromorphological restoration on the river ecological status: A comparison of fish, benthic invertebrates, and macrophytes. Hydrobiologia 2013, 704, 475-488. [CrossRef]

23. Doll, B.A.; Jennings, G.D.; Spooner, J.; Penrose, D.L.; Usset, J.L. Evaluating the eco-geomorphological condition of restored streams using visual assessment and macroinvetebrate metrics. J. Water Resour. Assoc. 2015, 51, 68-83. [CrossRef]

24. Doll, B.A.; Jennings, G.D.; Spooner, J.; Penrose, D.L.; Usset, J.L.; Blackwell, J.; Fernandez, M. Can rapid assessments predict the biotic condition of restored streams? Water 2016, 8, 143. [CrossRef]

25. Palmer, M.A.; Allan, J.D.; Meyer, J.; Bernhardt, E.S. River restoration in the twenty-first century: Data and experimental knowledge to inform future efforts. Restor. Ecol. 2007, 15, 472-481. [CrossRef]

26. Sudduth, E.B.; Hassett, B.A.; Cada, P.; Bernhardt, E.S. Testing the field of dreams hypothesis: Functional responses to urbanization and restoration in stream ecosystems. Ecol. Appl. 2011, 21, 1972-1988. [CrossRef] [PubMed]

27. Sedell, J.R.; Reeves, G.H.; Hauer, F.R.; Stanford, J.A.; Hawkins, C.P. Role of refugia in recovery from disturbances: Modern fragmented and disconnected river systems. Environ. Manag. 1990, 14, 711-724. [CrossRef]

28. Schlosser, I.J. Environmental variation, life history attributes, and community structure in stream fishes: Implications for environmental management and assessment. Environ. Manag. 1990, 14, 621-628. [CrossRef]

29. Kondolf, G.M. Geomorphological stream channel classification in aquatic habitat restoration: Uses and limitations. Aquat. Conserv. Mar. Freshw. Ecosyst. 1995, 5, 127-141. [CrossRef]

30. Sundermann, A.; Stoll, S.; Hasse, P. River restoration success depends on the species pool of the immediate surroundings. Ecol. Appl. 2009, 21, 1962-1971. [CrossRef]

31. Bernhardt, E.S.; Palmer, M.A. River restoration: The fuzzy logic of repairing reaches to reverse catchment scale degradation. Ecol. Appl. 2011, 21, 1921-1931. [CrossRef]

32. Schwartz, J.S. Stream Habitat Characterized by Stage-specific Flows and Three-dimensional Geomorphological Complexity: Development of Ecological Criteria for Stream Restoration Design. Ph.D. Thesis, University of Illinois at Urbana-Champaign, Champaign, IL, USA, June 2002; p. 246.

33. Lake, P.S.; Bond, N.; Reich, P. Linking ecological theory with stream restoration. Freshw. Biol. 2007, 52, 597-615. [CrossRef]

34. Schwartz, J.S. Influence of Geomorphology and Land Use on Distribution and Abundance of Salmonids in a Coastal Oregon Basin. Master's Thesis, Oregon State University, Corvallis, OR, USA, June 1991; p. 207. 
35. Gregory, S.V.; Swanson, F.J.; McKee, W.A.; Cummins, K.W. An ecosystem perspective of riparian zones. BioScience 1991, 41, 540-551. [CrossRef]

36. Frothingham, K.M.; Rhoads, B.L.; Herricks, E.E. A multiscale conceptual framework for integrated eco-geomorphological research to support stream naturalization in the agricultural Midwest. Environ. Manag. 2002, 29, 16-23. [CrossRef]

37. Beechie, T.J.; Sear, D.A.; Olden, J.D.; Pess, G.R.; Buffington, J.M.; Moir, H.; Roni, P.; Pollock, M.M. Process-based principles for restoring river ecosystems. BioScience 2010, 60, 209-222. [CrossRef]

38. Frissell, C.A.; Liss, W.J.; Warren, C.E.; Hurley, M.D. A hierarchical framework for stream habitat classification: Viewing streams in a watershed context. Environ. Manag. 1986, 10, 199-214. [CrossRef]

39. Pringle, C.M.; Naiman, R.J.; Bretschko, G.; Karr, J.R.; Oswood, M.W.; Webster, J.R.; Welcome, R.L.; Winterbourn, M.J. Patch dynamics in lotic systems: The stream as a mosaic. J. N. Am. Benthol. Soc. 1988, 7, 503-524. [CrossRef]

40. Townsend, C.R.; Doledec, S.; Scarbrook, M.R. Species traits in relation to temporal and spatial heterogeneity in streams: A test of habitat templet theory. Freshw. Biol. 1997, 37, 367-387. [CrossRef]

41. Townsend, C.R. The patch dynamics concept of stream community ecology. J. N. Am. Benthol. Soc. 1989, 8 , 36-50. [CrossRef]

42. Wu, J.; Loucks, O.L. From balance of nature to hierarchical patch dynamics: A paradigm shift in ecology. Q. Rev. Biol. 1995, 70, 439-466. [CrossRef]

43. Southwood, T.R.E. Habitat, the template for ecological strategies? J. Anim. Ecol. 1977, 46, 337-365. [CrossRef]

44. The Federal Interagency Stream Restoration Working Group (15 US Federal Agencies). Stream Corridor Restoration: Principles, Processes, and Practices; GPO Item No. 0120-A; FISRWG: Washington, DC, USA, 1998.

45. Yochum, S. Guidance for Stream Restoration; Engineering Technical Note No. 27.3; USDA Natural Resources Conservation Service: Denver, CO, USA, 2014; p. 77.

46. Ward, J.V. The four-dimensional nature of lotic ecosystems. J. N. Am. Benthol. Soc. 2089, 8, 3-8. [CrossRef]

47. Tockner, K.; Pennetzdorfer, D.; Reiner, N.; Schiemer, F.; Ward, J.V. Hydrological connectivity, and the exchange of organic matter and nutrients in a dynamic river-floodplain system (Danube, Austria). Freshw. Biol. 1999, 41, 521-535. [CrossRef]

48. Kondolf, G.M.; Boulton, A.J.; O’Daniel, S.; Poole, G.C.; Rahel, F.J.; Stanley, E.H.; Wohl, E.; Bang, A.; Carlstrom, J.; Cristoni, C.; et al. Process-based ecological river restoration: Visualizing three-dimensional connectivity and dynamic vectors to recover lost linkages. Ecol. Soc. 2006, 11, 1-5.

49. Thorp, J.H.; Thoms, M.C.; Delong, M.D. The riverine ecosystem synthesis: Biocomplexity in river networks across space and time. River Res. Appl. 2006, 22, 123-147. [CrossRef]

50. Vannote, R.L.; Minshall, G.W.; Cummins, K.W.; Sedell, J.R.; Cushing, C.E. The river continuum concept. Can. J. Fish. Aquat. Sci. 1980, 37, 130-137. [CrossRef]

51. Wiley, M.J.; Osborne, L.L.; Larimore, R.W. Longitudinal structure of an agricultural prairie river system and its relationship to current stream ecosystem theory. Can. J. Fish. Aquat. Sci. 1989, 47, 373-384. [CrossRef]

52. Junk, W.J.; Bayley, P.B.; Sparks, R.E. The flood pulse concept in river-floodplain systems. In Proceedings of the International Large River Symposium, Honey Harbour, Toronto, ON, Canada, 14-21 September 1989; Dodge, D.P., Ed.; Canadian Special Publication of Fisheries and Aquatic Sciences 106; Department of Fisheries and Oceans: Ottawa, ON, Canada, 1989; pp. 110-127.

53. Jansson, R.; Nilsson, C.; Malmqvist, B. Restoring freshwater ecosystems in riverine landscapes: The roles of connectivity and recovery processes. Freshw. Biol. 2007, 52, 589-596. [CrossRef]

54. Klocker, C.A.; Kaushal, S.S.; Groffman, P.M.; Mayer, P.M.; Morgan, R.P. Nitrogen uptake and denitrification in restored and unrestored streams in urban Maryland, USA. Aquat. Sci. 2009, 71, 411-424. [CrossRef]

55. Roley, S.S.; Tank, J.L.; Stephen, M.L.; Johnson, L.T.; Beaulieu, J.J.; Witter, J.D. Floodplain restoration enhances denitrification and reach-scale nitrogen removal in an agricultural stream. Ecol. Appl. 2012, 22, 281-297. [CrossRef] [PubMed]

56. Marzadri, A.; Tonina, D.; Bellin, A.; Tank, J.L. A hydrologic model demonstrates nitrous oxide emissions depend on streambed morphology. Geophys. Res. Lett. 2014, 41, 5484-5491. [CrossRef]

57. Palmer, M.A.; Ambrose, R.F.; Poff, N.L.R. Ecological theory and community restoration ecology. Restor. Ecol. 1997, 5, 291-300. [CrossRef] 
58. Hawkins, C.P.; Kershner, J.L.; Bisson, P.A.; Bryant, M.D.; Decker, L.M.; Gregory, S.V.; McCullough, D.A.; Overton, C.K.; Reeves, G.H.; Steedman, R.J.; et al. A hierarchical approach to classifying stream habitat features. Fisheries 1993, 18, 3-12. [CrossRef]

59. Newbury, R.; Gaboury, M. Exploration and rehabilitation of hydraulic habitats in streams using principals of fluvial behavior. Freshw. Biol. 1993, 29, 195-210. [CrossRef]

60. Ombredane, D.; Haury, J.; Chapon, P.M. Heterogeneity and typology of fish habitat in the main stream of a Breton coastal river. Hydrobiologia 1995, 300/301, 259-268. [CrossRef]

61. Bisson, P.A.; Montgomery, D.R. Valley segments, stream reaches, and channel units. In Methods in Stream Ecology; Hauer, R.F., Lambert, G.A., Eds.; Academic Press: San Diego, CA, USA, 1996; pp. $23-42$.

62. Vadas, R.L.; Orth, D.J. Use of physical variables to discriminate visually determined mesohabitat types in North American streams. Rivers 1998, 6, 143-159.

63. Bain, M.B.; Stephenson, N.J. Aquatic Habitat Assessment, Common Methods; American Fisheries Society: Bethesda, MD, USA, 1999; p. 216.

64. Kaufmann, P.R.; Levine, P.; Robison, E.G.; Seeliger, C.; Peck, D.V. Quantifying Physical Habitat in Wadeable Streams; EPA/620/R-99/003; U.S. Environmental Protection Agency: Washington, DC, USA, 1999.

65. U.S. Forest Service. Stream Inventory Handbook: Levels I and II; U.S. Forest Service, Pacific Northwest Region 6 Office: Portland, OR, USA, 2012; p. 127.

66. Barbour, M.T.; Gerritsen, J.; Snyder, B.D.; Stribling, J.B. Rapid Bioassessment Protocols for Use in Streams and Wadeable Rivers: Periphyton, Benthic Macroinvertebrates and Fish, 2nd ed.; EPA 841-B-99-002; U.S. Environmental Protection Agency, Office of Water: Washington, DC, USA, 1999.

67. Shields, F.D.; Knight, S.S.; Cooper, C.M. Use of the index of biotic integrity to assess physical habitat degradation in warmwater streams. Hydrobiologia 1995, 312, 191-208. [CrossRef]

68. Maddock, I. The importance of physical habitat assessment for evaluating river health. Freshw. Biol. 1999, 41, 373-391. [CrossRef]

69. Metzeling, L.; Chessman, B.; Hardwick, R.; Wong, V. Rapid assessment of rivers using macroinvertebrates: The role of experience, and comparisons with quantitative methods. Hydrobiologia 2003, 510, 39-52. [CrossRef]

70. Asmus, B.; Magner, J.A.; Vondracek, B.; Perry, J. Physical integrity: The missing link in biological monitoring and TMDLs. Environ. Monit. Assess. 2009, 159, 443-463. [CrossRef] [PubMed]

71. Knighton, D. Fluvial Forms and Processes; Edward Arnold Publisher: London, UK, 1998; p. 388.

72. Keller, E.A.; Melhorn, W.N. Rhythmic spacing and origin of pools and riffles. Geol. Soc. Am. Bull. 1978, 89, 723-730. [CrossRef]

73. Gregory, K.J.; Gurnell, A.M.; Hill, C.T.; Tooth, S. Stability of the pool-riffle sequence in changing river channels. Regul. Rivers Res. Manag. 1994, 9, 35-43. [CrossRef]

74. Sear, D.A. Sediment transport processes in pool-riffle sequences. Earth Surface Process. Landf. 1996, 21, 241-262. [CrossRef]

75. Clifford, N.J. Differential bed sedimentology and the maintenance of riffle-pool sequences. Catena 1993, 20, 447-468. [CrossRef]

76. Carling, P.A.; Orr, H.G. Morphology of riffle-pool sequences in the River Severn, England. Earth Surface Process. Landf. 2000, 25, 369-384. [CrossRef]

77. Rabeni, C.F.; Jacobson, J.B. The importance of fluvial hydraulics to fish-habitat restoration in low-gradient alluvial streams. Freshw. Biol. 1993, 29, 211-220. [CrossRef]

78. Allan, J.D.; Castillo, M.M. Stream Ecology, Structure and Function of Running Waters, 2nd ed.; Springer: Dordrecht, The Netherlands, 2007; p. 436.

79. Schwartz, J.S.; Herricks, E.E. Fish use of ecohydraulic-based mesohabitat units in a low-gradient Illinois stream: Implications for stream restoration. Aquat. Conserv. Mar. Freshw. Ecosyst. 2008, 18, 852-866. [CrossRef]

80. Clifford, N.J.; Harmar, O.P.; Harvey, G.; Petts, G.E. Physical habitat, ecohydraulics and river design: A review and re-evaluation of some popular concepts and methods. Aquat. Conserv. Mar. Freshw. Ecosyst. 2006, 16, 389-408. [CrossRef]

81. Rhoads, B.L.; Engel, F.L.; Abad, J.D. Pool-riffle design based on geomorphological principles for naturalizing straight channels. In Stream Restoration in Dynamic Fluvial Systems: Scientific Approaches, Analysis, and Tools; Simon, A., Bennett, S.J., Castro, J.M., Eds.; Geophysical Monograph Series 194; American Geophysical Union: Washington, DC, USA, 2011; pp. 367-384. 
82. Doyle, M.W.; Shields, F.D. Compensatory mitigation for streams under the Clean Water Act: Reassessing science and redirecting policy. J. Am. Water Recour. Assoc. 2012, 48, 494-509. [CrossRef]

83. Harman, W.; Starr, R.; Carter, M.; Tweedy, K.; Clemmons, M.; Suggs, K.; Miller, C. A Function-Based Framework for Stream Assessment and Restoration Projects; EPA 843-K-12-006; U.S. Environmental Protection Agency, Office of Wetlands, Oceans, and Watersheds: Washington, DC, USA, 2012; p. 340.

84. Palmer, M.A.; Bernhardt, E.S.; Allan, J.D.; Lake, P.S.; Alexander, G.; Brooks, S.; Carr, J.; Clayton, S.; Dahm, C.N.; Galat, D.L.; et al. Standards for ecologically successful river restoration. J. Appl. Ecol. 2005, 42, 208-217. [CrossRef]

85. Woolsey, S.; Capelli, F.; Gonser, T.; Hoehn, E.; Hostmann, M.; Junker, B.; Paetzold, A.; Roulier, C.; Schweizer, S.; Tiegs, S.D.; et al. A strategy to assess river restoration success. Freshw. Biol. 2007, 52, 752-769. [CrossRef]

86. Pander, J.; Geist, J. Ecological indicators for stream restoration success. Ecol. Indic. 2013, 30, 106-118. [CrossRef]

87. Wortley, L.; Hero, J.-M.; Howes, M. Evaluating ecological restoration success: A review of the literature. Restor. Ecol. 2013, 21, 537-543. [CrossRef]

88. Statzner, B.; Gore, J.A.; Resh, V.H. Hydraulic stream ecology: Observed patterns and potential applications. J. N. Am. Benthol. Soc. 1988, 7, 307-360. [CrossRef]

89. Shields, F.D.; Langendoen, E.J.; Doyle, M.W. Adapting existing models to examine effects of agricultural conservation programs on stream habitat quality. J. Am. Water Resour. Assoc. 2006, 42, 25-33. [CrossRef]

90. Maddock, I.; Harby, A.; Kemp, P.; Wood, P. Ecohydraulics: An Integrated Approach; John Wiley \& Sons, Ltd.: Hoboken, NJ, USA, 2013; pp. 1-6.

91. Schwartz, J.S.; Neff, K.J.; Dworak, F.J.; Woockman, R.R. Restoring riffle-pool structure in an incised, straightened urban stream channel using an ecohydraulic modeling approach. Ecol. Eng. 2015, 78, 112-126. [CrossRef]

92. Orth, D.J.; Maughan, O.E. Evaluation of incremental methodology for recommending instream flows for fishes. Trans. Am. Fish. Soc. 1982, 111, 413-445. [CrossRef]

93. Bovee, K.D.; Lamb, B.L.; Bartholow, J.M.; Stalnaker, C.B.; Taylor, J.; Henroksen, J. Stream Habitat Analysis Using the Instream Flow Incremental Methodology; U.S. Geological Survey, Biological Resources Division Information and Technology Report: Fort Collins, CO, USA, March 1998.

94. Vadas, R.L.; Orth, D.J. Formulation of habitat suitability models for stream fish guilds: Do the standard methods work? Trans. Am. Fish. Soc. 2001, 130, 217-235. [CrossRef]

95. Persinger, J.W.; Orth, D.J.; Averett, A.W. Using habitat guilds to development habitat suitability criteria for warmwater stream fish assemblages. River Res. Appl. 2011, 27, 956-966. [CrossRef]

96. Schwartz, J.S.; Herricks, E.E. Use of prepositioned areal electrofishing devices with rod electrodes in small streams. N. Am. J. Fish. Manag. 2004, 24, 1330-1340. [CrossRef]

97. Lanchester, J.; Downes, B.J. Linking the hydraulic world of individual organisms to ecological processes: Putting ecology into ecohydraulics. River Res. Appl. 2010, 26, 385-403. [CrossRef]

98. Benjankar, R.; Tonina, D.; McKean, J. One-dimensional and two-dimensional hydrodynamic modeling derived flow properties: Impacts on aquatic habitat quality predictions. Earth Surface Process. Landf. 2015, 40, 340-356. [CrossRef]

99. Tonina, D.; Jorde, K. Hydraulic modeling approaches for ecohydraulic studies: 3D. 2D, 1D and non-numerical models. In Ecohydraulics: An Integrated Approach; Maddock, I., Harby, A., Kemp, P., Wood, P., Eds.; John Wiley \& Sons, Ltd.: Hoboken, NJ, USA, 2013; pp. 31-74.

100. LeClerc, M.; Boudreault, A.; Bechara, J.A.; Corfa, G. Two-dimensional hydrodynamic modeling: A neglected tool in the instream flow incremental methodology. Trans. Am. Fish. Soc. 1995, 124, 645-662. [CrossRef]

101. Booker, D.J.; Dunbar, M.J. Application of physical habitat simulation (PHABSIM) modelling to modified urban river channels. River Res. Appl. 2004, 20, 167-183. [CrossRef]

102. Pasternack, G.B.; Wang, C.L.; Merz, J.E. Application of a 2D hydrodynamic model to design of reach-scale spawning gravel replenishment on the Mokelumme River, California. River Res. Appl. 2004, 20, 205-225. [CrossRef]

103. Steffler, P.; Blackburn, J. River2D, Two-Dimensional Depth Averaged Model of River Hydrodynamics and Fish Habitat, Introduction to Depth Averaged Modeling and User's Manual; University of Alberta: Edmonton, AB, Canada, 2002.

104. Schwartz, J.S. Use of a 2D Hydrodynamic Model for Stream Restoration Design of High-flow Habitat in Low-gradient Midwest Streams. In Proceedings of the Symposium on Protection and Restoration of Urban and Rural Streams, Philadelphia, PA, USA, 23-25 June 2003; Clar, M., Carpenter, D., Gracie, J., Slate, L., Eds.; American Society of Civil Engineers: Reston, VA, USA, 2003; pp. 242-251. 
105. Parasiewicz, P. MesoHABSIM: A concept for application of instream flow models in river restoration. Fisheries 2001, 26, 6-13. [CrossRef]

106. Parasiewicz, P. Using MesoHABSIM to develop reference habitat template and ecological management scenarios. River Res. Appl. 2007, 23, 924-932. [CrossRef]

107. Lamouroux, N.; Capra, H.; Pouilly, M. Predicting habitat suitability for lotic fish: Linking statistical models with multivariate habitat use models. Regul. Rivers Res. Manag. 1998, 14, 1-11. [CrossRef]

108. Bain, M.B.; Meixler, M.S. A target fish community to guide river restoration. River Res. Appl. 2008, 24, 453-458. [CrossRef]

109. Mueller, M.; Pander, J.; Geist, J. The ecological value of stream restoration measures: An evaluation on ecosystem and target species scales. Ecol. Eng. 2014, 62, 129-139. [CrossRef]

110. Lacey, R.W.J.; Millar, R.G. Reach scale hydraulic assessment of instream salmonid habitat restoration. J. Am. Water Resour. Assoc. 2004, 40, 1631-1644. [CrossRef]

111. Parasiewicz, P. Applications of MesoHABSIM and target fish community approaches to restoration of the Quinebaug River, Connecticut and Massachusetts, USA. River Res. Appl. 2008, 24, 459-471. [CrossRef]

112. Brown, R.A.; Pasternack, G.B. Comparison of methods for analyzing salmon habitat rehabilitation designs for regulated rivers. River Res. Appl. 2009, 25, 745-772. [CrossRef]

113. Frimpong, E.A.; Angermeier, P.L. Trait-based approaches in the analysis of fish communities. Am. Fish. Soc. Symp. 2010, 73, 109-136.

114. Poff, N.L. Landscape filters and species traits: Towards mechanistic understanding and prediction in stream ecology. J. N. Am. Benthol. Soc. 1997, 16, 391-409. [CrossRef]

115. Belyea, L.R.; Lancaster, J. Assembly rules within a contingent ecology. Oikos 1999, 86, 402-416. [CrossRef]

116. Poff, N.L.; Olden, J.D.; Nieira, K.M.; Finn, D.S.; Simmons, M.P.; Kondratieff, B.C. Functional trait niches of North American lotic insects: Traits-based ecological applications in light of phylogenetic relationships. J. N. Am. Benthol. Soc. 2006, 25, 730-755. [CrossRef]

117. Statzner, B.; Beche, L.A. Can biological traits resolve effects of multiple stressors on running water ecosystems? Freshw. Biol. 2010, 55, 80-119. [CrossRef]

118. Keck, B.P.; Marion, Z.H.; Martin, D.J.; Kaufman, J.C.; Harden, C.P.; Schwartz, J.S.; Strange, R.J. Fish functional traits correlated with environmental traits in a temperate biodiversity hot spot. PLoS ONE 2014, 9, e93237. [CrossRef] [PubMed]

119. Poff, N.L.; Allan, J.D. Functional organization of stream fish assemblages in relation to hydrological variability. Ecology 1995, 76, 606-627. [CrossRef]

120. Kemp, J.L.; Harper, D.M.; Cross-Giuseppe, A. Use of "functional habitats" to link ecology with morphology and hydrology in river restoration. Aquat. Conserv. 1999, 9, 159-178. [CrossRef]

121. Newson, M.D.; Newson, C.L. Geomorphology, ecology and river channel habitat: Mesoscale approaches to basin-scale challenges. Prog. Phys. Geogr. 2000, 24, 195-217. [CrossRef]

122. Jackson, D.A.; Peres-Neto, P.R.; Olden, J.D. What controls who is where in freshwater fish communities-The roles of biotic, abiotic, and spatial factors. Can. J. Fish. Aquat. Sci. 2001, 58, 157-170.

123. Lamouroux, N.; Olivier, J.; Persat, H.; Pouilly, M.; Souchon, Y.; Statzner, B. Predicting community characteristics from habitat conditions: Fluvial fish and hydraulics. Freshw. Biol. 1999, 42, 275-299. [CrossRef]

124. Lamouroux, N.; Poff, N.L.; Angermeier, P.L. Intercontinental convergence of fish community traits along geomorphic and hydraulic gradients. Ecology 2002, 83, 1792-1807. [CrossRef]

125. Bayley, P.B.; Li, H.W. Riverine fishes. In River Biota: Diversity and Dynamics; Petts, G., Calow, P., Eds.; Blackwell Science Ltd.: London, UK, 1996; pp. 92-122.

126. Palmer, M.A.; Hakenkamp, C.C.; Nelson-Baker, K. Ecological heterogeneity in streams: Why variance matters. J. N. Am. Benthol. Soc. 1997, 16, 189-202. [CrossRef]

127. Amoros, C. The concept of habitat diversity between and within ecosystems applied to river side-arm restoration. Environ. Manag. 2001, 28, 805-817. [CrossRef]

128. Buffington, J.M.; Montgomery, D.R. Geomorphic classification of rivers. In Treatise on Geomorphology; Fluvial Geomorphology; Volume 9, Shroder, J., Wohl, E., Eds.; Academic Press: San Diego, CA, USA, 2013; pp. 730-767.

129. Wolman, M.G.; Miller, J.P. Magnitude and frequency of forces in geomorphic processes. J. Geol. 1960, 68, 54-74. [CrossRef] 
130. Ackers, P.; Charlton, F.G. Dimensional analysis of alluvial channels with special reference to meander length. J. Hydraul. Res. 1976, 8, 287-316. [CrossRef]

131. Richards, K.S. The morphology of riffle-pool sequences. Earth Surf. Process. Landf. 1976, 1, 71-88. [CrossRef]

132. Rosgen, D.L. A classification of natural rivers. Catena 1994, 22, 169-199. [CrossRef]

133. Wolman, M.G.; Leopold, L.B. River flood plains: Some observations on their formation. U.S. Geol. Surv. Prof. Pap. 1957, 282C, 87-109.

134. Page, K.; Nanson, G. Concave-bank benches and associated floodplain formation. Earth Surf. Process. Landf. 1982, 7, 529-543. [CrossRef]

135. Nanson, G.C.; Croke, J.C. A genetic classification of floodplains. Geomorphology 1992, 4, 459-486. [CrossRef]

136. Dietrich, W.E. Mechanics of flow and sediment transport in river bends. In River Channel Environment and Process; Richards, K., Ed.; Blackwell Press: Basil, Russia, 1987; pp. 179-227.

137. Hooke, J.M. River channel adjustment to meander cutoffs on the River Bolin and River Dane, northwest England. Geomorphology 1995, 14, 235-253. [CrossRef]

138. Montgomery, D.R.; Buffington, J.M. Channel-reach morphology in mountain drainage basins. Geol. Soc. Am. Bull. 1997, 109, 596-611. [CrossRef]

139. Montgomery, D.R.; Buffington, J.M.; Smith, R.D.; Schmidt, K.M.; Pess, G. Pool spacing in forest channels. Water Resour. Res. 1995, 31, 1097-1105. [CrossRef]

140. Keller, E.A.; Florsheim, J.L. Velocity-reversal hypothesis: A model approach. Earth Surf. Process. Landf. 1993, 18, 733-740.

141. Cao, Z.; Carling, P.; Oakley, R. Flow reversal over a natural pool-riffle sequence: A computational study. Earth Surf. Process. Landf. 2003, 28, 689-705. [CrossRef]

142. Wilkinson, S.N.; Keller, R.J.; Rutherfund, I.D. Phase-shifts in shear stress as an explanation for the maintenance of pool-riffle sequences. Earth Surf. Process. Landf. 2004, 29, 737-753. [CrossRef]

143. Smith, D.L.; Brannon, E.L. Influence of cover on mean column hydraulic characteristics in small pool-riffle morphology streams. River Res. Appl. 2007, 23, 125-139. [CrossRef]

144. Colombini, M.; Seminara, G.; Tubino, M. Finite-amplitude alternate bars. J. Fluid Mech. 1987, 181, $213-232$. [CrossRef]

145. Whiting, P.J.; Dietrich, W.E. Convective accelerations and boundary shear stress over a channel bar. Water Resour. Res. 1991, 27, 783-796. [CrossRef]

146. Lanzoni, S.; Tubino, M. Grain sorting and bar instability. J. Fluid Mech. 1999, 393, 149-174. [CrossRef]

147. Frothingham, K.M.; Rhoads, B.L. Three-dimensional flow structure and channel change in an asymmetrical compound meander loop, Embarras River, Illinois. Earth Surf. Process. Landf. 2003, 28, 625-644. [CrossRef]

148. Biron, P.M.; Carver, R.B.; Carre, D.M. Sediment transport and flow dynamics around a restored pool in a fish habitat rehabilitation project: Field and 3D numerical modeling experiments. River Res. Appl. 2012, 28, 926-939. [CrossRef]

149. Dietrich, W.E.; Smith, J.D. Influence of the point bar on flow through curved channels. Water Resour. Res. 1983, 19, 1173-1192. [CrossRef]

150. Nelson, J.M.; Bennett, J.P.; Wiele, S.M. Flow and sediment-transport modeling. In Tools in Fluvial Geomorphology; Kondolg, M.G., Piegay, H., Eds.; John Wiley \& Sons, Ltd.: Hoboken, NJ, USA, 2003; pp. 539-576.

151. Rhoads, B.L.; Kenworthy, S.T. Flow structure at an asymmetrical stream confluence. Geomorphology 1995, 11, 273-293. [CrossRef]

152. Rodriguez, J.F.; Garcia, C.M.; Garcia, M.H. Three-dimensional flow in centered pool-riffle sequences. Water Resour. Res. 2013, 49, 202-215. [CrossRef]

153. Booker, D.; Sear, D.; Payne, A. Modelling three-dimensional flow structures and patterns of boundary shear stress in a natural pool-riffle sequence. Earth Surf. Process. Landf. 2001, 26, 553-576. [CrossRef]

154. MacWilliams, M.L.; Wheaton, J.M.; Pasternack, G.B.; Street, R.L.; Kitanidis, P.K. Flow convergence routing hypothesis for pool-riffle maintenance in alluvial rivers. Water Resour. Res. 2006, 42, 1-22. [CrossRef]

155. Caamano, D.; Goodwin, P.; Buffington, J.M.; Liou, J.C.; Daley-Laursen, S. Unifying criterion for the velocity reversal hypothesis in gravel-bed rivers. J. Hydraul. Eng. 2009, 135, 66-70. [CrossRef]

156. MacVicar, B.J.; Roy, A.G. Sediment mobility in a forced riffle-pool. Geomorphology 2011, 125, 445-456. [CrossRef]

157. Caamano, D.; Goodwin, P.; Buffington, J.M. Flow structure through pool-riffle sequences and a conceptual model for their sustainability in gravel-bed rivers. River Res. Appl. 2012, 28, 377-389. [CrossRef] 
158. Milan, D.J. Sediment routing hypothesis for pool-riffle maintenance. Earth Surf. Process. Landf. 2013, 38, 1623-1641. [CrossRef]

159. Pasternack, G.B.; Brown, R.A. Ecohydraulic design of riffle-pool relief and morphological unit geometry in support of regulated gravel-bed river rehabilitation. In Ecohydraulics: An Integrated Approach; Maddock, I., Harby, A., Kemp, P., Wood, P., Eds.; John Wiley \& Sons, Ltd.: Hoboken, NJ, USA, 2013; pp. 337-355.

160. Crowder, D.W.; Diplas, P. Vorticity and circulation: Spatial metrics for evaluating flow complexity in stream habitats. Can. J. Fish. Aquat. Sci. 2002, 59, 633-645. [CrossRef]

161. Gurnell, A.M.; Sweet, R. The distribution of large woody debris accumulations and pools in relation to woodland stream management in a small, low-gradient stream. Earth Surf. Process. Landf. 1998, 23, 1101-1121. [CrossRef]

162. Myers, T.; Swanson, F.J. Variability of pool characteristics with pool type and formative feature on small Great Basin rangeland streams. J. Hydrol. 1997, 201, 62-81. [CrossRef]

163. Thompson, D.M.; Hoffman, K.S. Equilibrium pool dimensions and sediment-sorting patterns in coarse-grained, New England channels. Geomorphology 2001, 38, 301-316. [CrossRef]

164. Buffington, J.M.; Lisle, T.E.; Woodsmith, R.D.; Hilton, S. Controls on the size and occurrence of pools in coarse-grained forest rivers. River Res. Appl. 2002, 18, 507-531. [CrossRef]

165. Power, M.E.; Stout, R.J.; Cushing, C.E.; Harper, P.P.; Hauer, F.R.; Matthews, W.J.; Moyle, P.B.; Statzner, B.; Wais De Badgen, I.R. Biotic and abiotic controls in rivers and stream communities. J. N. Am. Benthol. Soc. 1988, 7, 456-479. [CrossRef]

166. Horwitz, R.J. Temporal variability patterns and the distributional patterns of stream fishes. Ecol. Monogr. 1978, 48, 307-321. [CrossRef]

167. Schlosser, I.J. Fish community structure and function along two habitat gradients in a headwater stream. Ecol. Monogr. 1982, 52, 395-414. [CrossRef]

168. Grenouillet, G.; Pont, D.; Herisse, C. Within-basin fish assemblage structure: The relative influence of habitat versus stream spatial position on local species richness. Can. J. Fish. Aquat. Sci. 2004, 61, 93-102. [CrossRef]

169. Li, R.Y.; Gelwick, F.P. The relationship of environmental factors to spatial and temporal variation of fish assemblages in a floodplain river in Texas, USA. Ecol. Freshw. Fish 2005, 14, 319-330. [CrossRef]

170. Merigoux, S.; Doledec, S.; Statzner, B. Species traits in relation to habitat variability and state: Neotrophic juvenile fish in floodplain creeks. Freshw. Biol. 2001, 46, 1251-1267. [CrossRef]

171. Taylor, C.M.; Warren, M.L., Jr. Dynamics in species composition of stream fish assemblages: Environmental variability and nested subsets. Ecology 2001, 82, 2320-2330. [CrossRef]

172. Angermeier, P.L. Resource seasonality and fish diets in an Illinois stream. Environ. Biol. Fish. 1982, 7, $251-264$. [CrossRef]

173. Ingersoll, C.G.; Hlohowskyj, I.; Mundahl, N.D. Movements and densities of the darters Etheostoma Flabellare, E. Spectabile, and E. Nigrum During Spring Spawning. J. Freshw. Ecol. 1984, 2, 345-351. [CrossRef]

174. Langhurst, R.W.; Schoenike, D.L. Seasonal migration of smallmouth bass in the Embarrass and Wolf Rivers, Wisconsin. N. Am. J. Fish. Manag. 1990, 10, 224-227. [CrossRef]

175. Matthews, W.J. Spatial and temporal variation in fishes of riffle habitats: A comparison of analytical approaches for the Roanoke River. Am. Midl. Nat. 1990, 124, 31-45. [CrossRef]

176. Vadas, R.L. Seasonal habitat use, species associations, and assemblage structure of forage fishes in Goose Creek, northern Virginia. I. macrohabitat patterns. Freshw. Ecol. 1991, 6, 403-417. [CrossRef]

177. Dewey, M.R. Seasonal abundance, movement and diversity of fishes in an Ozark stream. Ark. Acad. Sci. Proc. 1981, 35, 33-39.

178. Smith, P.W. A study of seasonal distribution of fishes in the Kaskaskia River ditch, a highly modified stream in eastern Illinois. Copeia 1963, 2, 251-259. [CrossRef]

179. Smith, P.W. The Fishes of Illinois; University of Illinois Press: Urbana, IL, USA, 1979; pp. 1-314.

180. Poff, N.L.; Ward, J.V. Implications of streamflow variability and predictability for lotic community structure: A regional analysis of streamflow patterns. Can. J. Fish. Aquat. Sci. 1989, 46, 1805-1818. [CrossRef]

181. Kelsch, S.W. Lotic fish-community structure following transition from severe drought to high discharge. J. Freshw. Ecol. 1994, 9, 331-341. [CrossRef]

182. Poff, N.L.; Allan, J.D.; Bain, M.B.; Karr, J.R.; Prestegaard, K.L.; Richter, B.D.; Sparks, R.E.; Stromberg, J.C. The natural flow regime. BioScience 1997, 47, 769-784. [CrossRef] 
183. Ross, S.T.; Baker, J.A. The response of fishes to periodic spring floods in a Southeastern stream. Am. Midl. Nat. 1983, 109, 1-14. [CrossRef]

184. Kwak, T.J. Lateral movement and use of floodplain habitat by fishes of the Kankakee River, Illinois. Am. Midl. Nat. 1988, 120, 241-249. [CrossRef]

185. Lancaster, J.; Hildrew, A.G. Characterizing in-stream flow refugia. Can. J. Fish. Aquat. Sci. 1993, 50, $1663-1675$. [CrossRef]

186. Niemi, G.J.; DeVore, P.; Detenbeck, N.; Taylor, D.; Lima, A.; Pastor, J.; Yount, J.D.; Naiman, R.J. Overview of case studies on recovery aquatic ecosystems from disturbance. Environ. Manag. 1990, 14, 571-587. [CrossRef]

187. Reice, S.R.; Wissmar, R.C.; Naiman, R.J. Disturbance regimes, resilience, and recovery of animal communities and habitats in lotic ecosystems. Environ. Manag. 1990, 14, 647-659. [CrossRef]

188. Matthews, W.J. Fish faunal structure in an Ozark stream: Stability, persistence, and a catastrophic flood. Copeia 1986, 2, 388-397. [CrossRef]

189. Pearsons, T.N.; Li, H.W.; Lamberti, G.A. Influence of habitat complexity on resistance to flooding and resilience of stream fish assemblages. Trans. Am. Fish. Soc. 1992, 121, 427-436. [CrossRef]

190. Lobón-Cerviá, J. Response of a stream fish assemblage to a severe spate in northern Spain. Trans. Am. Fish. Soc. 1996, 125, 913-919. [CrossRef]

191. Fausch, K.D.; Bramblett, R.G. Disturbance and fish communities in intermittent tributaries of a Western Great Plains river. Copeia 1991, 3, 659-673. [CrossRef]

192. Lohr, S.C.; Fausch, K.D. Multiscale analysis of natural variability in stream fish assemblages of a western Great Plains watershed. Copeia 1997, 4, 706-724. [CrossRef]

193. Larimore, R.W.; Garrels, D.D. Assessing habitats used by warmwater stream fishes. Fisheries 1985, 10, 10-16. [CrossRef]

194. Schlosser, I.J. The role of predation in age- and size-related habitat use by stream fishes. Ecology 1987, 68, 651-659. [CrossRef]

195. Gelwick, F.P. Longitudinal and temporal comparisons of riffle and fish pool assemblages in a northeastern Oklahoma Ozark stream. Copeia 1990, 4, 1072-1082. [CrossRef]

196. Lobb, M.D.; Orth, D.J. Habitat use by an assemblage of fish in a large warmwater stream. Trans. Am. Fish. Soc. 1991, 120, 65-78. [CrossRef]

197. Aadland, L.P. Stream habitat types: Their assemblages and relationship to flow. N. Am. J. Fish. Manag. 1993, 13, 790-806. [CrossRef]

198. Matthews, W.J.; Harvey, B.C.; Power, M.E. Spatial and temporal patterns in fish assemblages of individual pools in a Midwestern stream. Environ. Biol. Fish. 1994, 39, 381-397. [CrossRef]

199. Lonzarich, D.G.; Lonzarich, M.R.; Warren, M.L., Jr. Effects of riffle length on the short-term movement of fishes among stream pools. Can. J. Fish. Aquat. Sci. 2000, 57, 1508-1514. [CrossRef]

200. Bisson, P.A.; Sullivan, K.; Nielsen, J.L. Channel hydraulics, habitat use, and body form of juvenile coho salmon, steelhead, and cutthroat trout in streams. Trans. Am. Fish. Soc. 1988, 117, 262-273. [CrossRef]

201. Schlosser, I.J. Predation rates and the behavioral response of adult brassy minnows (Hybognathus hankinsoni) to creek chub and smallmouth bass predators. Copeia 1988, 3, 691-697. [CrossRef]

202. Hearn, W.E. Interspecific competition and habitat segregation among stream-dwelling trout and salmon: A review. Fisheries 1987, 12, 24-31. [CrossRef]

203. Frissell, C.A.; Lonzarich, D.G. Habitat use and competition among stream fishes. In Methods in Stream Ecology; Hauer, R.F., Lambert, G.A., Eds.; Academic Press: San Diego, CA, USA, 1996; pp. 493-510.

204. Schlosser, I.J. Flow regime, juvenile abundance, and the assemblage structure on stream fishes. Ecology 1985, 66, 1484-1490. [CrossRef]

205. Moore, K.M.S.; Gregory, S.V. Summer habitat utilization and ecology of cutthroat trout fry (Salmo clarki) in Cascade Mountain streams. Can. J. Fish. Aquat. Sci. 1988, 45, 1921-1930. [CrossRef]

206. Payne, B.A.; Lapointe, M.F. Channel morphology and lateral stability: Effects on distribution of spawning and rearing habitat for Atlantic salmon in a wandering cobble-bed river. Can. J. Fish. Aquat. Sci. 1997, 54, 2627-2636. [CrossRef]

207. Bain, M.B.; Finn, J.T.; Brooke, H.E. Streamflow regulations and fish community structure. Ecology 1988, 69, 382-392. [CrossRef]

208. Rakocinski, C. Population structure of stream-dwelling darters: Correspondence with habitat structure. Environ. Biol. Fish. 1988, 23, 215-224. [CrossRef] 
209. Hayes, J.W.; Jowett, I.G. Microhabitat models of large drift-feeding brown trout in three New Zealand rivers. N. Am. J. Fish. Manag. 1994, 14, 710-725. [CrossRef]

210. McMahon, T.E.; Hartman, G.F. Influence of cover complexity and current velocity on winter habitat use by juvenile coho salmon (Oncorhynchus kisutch). Can. J. Fish. Aquat. Sci. 1989, 46, 1551-1557. [CrossRef]

211. Blanck, A.; Tedesco, P.A.; Lamouroux, N. Relationships between life-history strategies of European freshwater fish species and their habitat preferences. Freshw. Biol. 2007, 52, 843-859. [CrossRef]

212. Jowett, I.G.; Duncan, M.J. Flow variability in New Zealand Rivers and its relationship to instream habitat and biota. N. Z. J. Mar. Freshw. Res. 1990, 24, 305-318. [CrossRef]

213. Yu, S.; Peters, E.J. Use of Froude number to determine habitat selection by fish. Rivers 1997, 6, 10-18.

214. Tyler, J.A.; Clapp, D.P. Perceptual constraints on stream fish habitat selection: Effects of food availability and water velocity. Ecol. Freshw. Fish 1995, 4, 9-16. [CrossRef]

215. Litvak, M.K.; Hansell, R.I.C. Investigation of food habit and niche relationships in a cyprinid community. Can. J. Zool. 1990, 68, 1873-1897. [CrossRef]

216. Schlosser, I.J.; Ebel, K.K. Effects of flow regime and cyprind predation on a headwater stream. Ecol. Monogr. 1989, 59, 41-57. [CrossRef]

217. Curry, K.D.; Spacies, A. Differential use of stream habitat by spawning Catostomids. Am. Midl. Nat. 1983, 111, 267-279. [CrossRef]

218. Emery, J.C.; Gurnell, A.M.; Clifford, N.J.; Petts, G.E.; Morrissey, I.P.; Soar, P.J. Classifying the hydraulic performance of riffle-pool bedforms for habitat assessment and river rehabilitation design. River Res. Appl. 2003, 19, 553-549. [CrossRef]

219. Clifford, N.J.; Soar, P.J.; Harmar, O.P.; Gurnell, A.M.; Petts, G.E.; Emery, J.C. Assessment of hydrodynamic simulation results for eco-hydraulic and eco-hydrological applications: A spatial semivariance approach. Hydrol. Process. 2005, 19, 3631-3648. [CrossRef]

220. Nester, J.M.; Stewardson, M.J.; Gilvear, D.; Webb, J.A.; Smith, D.L. Ecohydraulics exemplifies the emerging "paradigm of the interdisciplines". J. Ecohydraul. 2016, in press.

221. Holm, E. Environmental restraints and life strategies: A habitat templat matrix. Oecologia 1988, 75, 141-145. [CrossRef]

222. Matthews, W.J. Patterns in Freshwater Ecology; Kluwer Academic Press: Norwell, MA, USA, 1988; p. 616.

223. Persat, H.; Olivier, J.; Pont, D. Theoretical habitat templats, species traits, and species richness: Fish in the Upper Rhone River and its floodplain. Freshw. Biol. 1994, 31, 439-454. [CrossRef]

224. Doledec, S.; Statzner, B.; Bournard, M. Species traits for future biomonitoring across ecoregions: Patterns along a human-impacted river. Freshw. Biol. 1999, 42, 737-758. [CrossRef]

225. Goldstein, R.M.; Meador, M.R. Comparison of fish species traits from small streams to large rivers. Trans. Am. Fish. Soc. 2004, 133, 971-983. [CrossRef]

226. Lamouroux, N.; Cattaneo, F. Fish assemblages and stream hydraulics consistent relations across spatial scales and regions. River Res. Appl. 2006, 22, 727-737. [CrossRef]

227. Goldstein, R.M.; Meador, M.R. Multilevel assessment of fish species traits to evaluate habitat degradation in streams of the upper Midwest. N. Am. J. Fish. Manag. 2005, 25, 180-194. [CrossRef]

228. McGill, B.J.; Enquist, B.J.; Weiher, E.; Westoby, M. Building community ecology from functional traits. Trends Ecol. Evolut. 2006, 21, 178-185. [CrossRef] [PubMed]

229. Simberloff, D.; Dayan, T. The guild concept and the structure of ecological communities. Ann. Rev. Ecol. Syst. 1991, 22, 115-143. [CrossRef]

230. Austen, D.J.; Bayley, P.B.; Menzel, B.W. Importance of the guild concept to fisheries research and management. Fisheries 1994, 19, 12-20. [CrossRef]

231. Welcomme, R.L.; Winemiller, K.O.; Cowx, I.G. Ecological guilds as a tool for environmental impact assessment in rivers. River Res. Appl. 2006, 22, 377-396. [CrossRef]

232. Karr, J.R. Biological integrity: A long-neglected aspect of water resource management. Ecol. Appl. 1991, 1, 165-222. [CrossRef] [PubMed]

233. Karr, J.R.; Yant, P.R.; Fausch, K.D.; Schlosser, I.J. Spatial and temporal variability of the index of biological integrity in three Midwestern streams. Trans. Am. Fish. Soc. 1987, 116, 1-11. [CrossRef]

234. Karr, J.R. Defining and assessing ecological integrity: Beyond water quality. In Environmental Toxicology and Chemistry; Ward, C.H., Ed.; Pergamon Press: Tarrytown, NY, USA, 1993; pp. 1521-1531. 
235. Hughes, R.M.; Kaufman, P.R.; Herlihy, A.T.; Kincald, T.M.; Reynolds, L.; Larsen, D.P. A process for developing and evaluating indices of fish assemblage integrity. Can. J. Fish. Aquat. Sci. 1998, 55, 1618-1631. [CrossRef]

236. Simon, T.P. Assessing the Sustainability and Biological Integrity of Water Resources Using Fish Communities; CRC Press, LLC.: Boca Raton, FL, USA, 1999; p. 671.

237. Rheinhardt, R.D.; Rheinhardt, M.C.; Brinson, M.M.; Faser, K.E. Application of reference data for assessing and restoring headwater ecosystems. Restor. Ecol. 1999, 7, 241-251. [CrossRef]

238. Berkman, H.E.; Rabeni, C.F. Effects of siltation on stream communities. Environ. Biol. Fish. 1987, 18, $285-294$. [CrossRef]

239. Rashleigh, B. Relation of environmental characteristics to fish assemblages in the Upper French Broad River Basin, North Carolina. Environ. Monit. Assess. 2004, 93, 139-156. [CrossRef] [PubMed]

240. Roy, A.H.; Freeman, M.C.; Freeman, B.J.; Wenger, S.J.; Ensign, W.E. Investigating hydrologic alternation as a mechanism of fish assemblage shifts in urbanizing streams. J. N. Am. Benthol. Soc. 2005, 24, 656-678. [CrossRef]

241. Brown, L.R.; Gregory, T.R.; May, J.T. Relation of urbanization to stream fish assemblages and species traits in nine metropolitan areas in the United States. Urban Ecosyst. 2009, 12, 391-416. [CrossRef]

242. Schwartz, J.S.; Simon, A.; Klimetz, L. Use of fish functional traits to associate in-stream suspended sediment transport metrics with biological impairment. Environ. Monit. Assess. 2011, 179, 347-369. [CrossRef] [PubMed]

243. Doledec, S.; Chessel, D.; ter Braak, C.J.F.; Champely, S. Matching species traits to environmental variables: A new three-table ordination method. Environ. Ecol. Stat. 1996, 3, 143-166. [CrossRef]

244. Dray, S.; Legendre, P. Testing the species traits-environmental relationships: Thefourth corner problem revisited. Ecology 2008, 89, 3400-3412. [CrossRef] [PubMed]

245. Frimpong, E.A.; Angermeier, P.L. Fish traits: A database of ecological and life-history traits of freshwater fishes of the United States. Fisheries 2009, 34, 487-495. [CrossRef]

246. Padmore, C.L. The role of physical biotopes in determining the conservation status and flow requirements of British rivers. Aquat. Ecosyst. Health Manag. 1998, 1, 25-35. [CrossRef]

247. Montgomery, D.R.; Buffington, J.M. Channel processes, classification, and response. In River Ecology and Management; Naiman, R., Bilby, R., Eds.; Springer: New York, NY, USA, 1998; pp. 13-42.

248. Kocik, J.F.; Ferreri, C.P. Juvenile production variation in salmonids: Population dynamics, habitat, and the role of spatial relationships. Can. J. Fish. Aquat. Sci. 1998, 55, 191-200. [CrossRef]

249. Newson, M.D.; Harper, D.M.; Padmore, C.L.; Kemp, J.K.; Vogel, B. A cost-effective approach for linking habitats, flow types and species requirements. Aquat. Conserv. Mar. Freshw. Ecosyst. 1998, 8, 431-446. [CrossRef]

250. Giberson, D.J.; Caissie, D. Stream habitat hydraulics: Interannual variability in three reaches of the Catamaran Brook, New Brunswick. Can. J. Fish. Aquat. Sci. 1998, 55, 485-494. [CrossRef]

251. Wadeson, R.A.; Rowntree, K.M. Application of the hydraulic biotope concept to the classification of instream habitats. Aquat. Ecosyst. Health Manag. 1998, 1, 143-157. [CrossRef]

252. Goldstein, R.M.; Meador, M.R.; Ruhl, K.E. Relative influence of streamflows in assessing temporal variability in stream habitat. J. Am. Water Resour. Assoc. 2007, 43, 642-650. [CrossRef]

253. Schwartz, J.S.; Herricks, E.E. Fish use of stage-specific fluvial habitats as refuge patches during a flood in a low-gradient Illinois stream. Can. J. Fish. Aquat. Sci. 2005, 62, 1540-1552. [CrossRef]

254. Lawless, M.; Robert, A. Three-dimensional flow structure around small-scale bedforms in a simulated gravel-bed environment. Earth Surf. Process. Landf. 2001, 26, 507-522. [CrossRef]

255. Lawless, M.; Robert, A. Scales of boundary resistance in course-grained channels: Turbulent velocity profiles and implications. Geomorphology 2001, 39, 221-238. [CrossRef]

256. Noss, C.; Salzmann, T.; Storchenegger, I. Turbulent and advective momentum fluxes in streams. Water Resour. Res. 2010, 46, 1-13. [CrossRef]

257. Yalin, M.S. River Mechanics; Pergamon Press: New York, NY, USA, 1992; p. 219.

258. Buffin-Belanger, T.; Roy, A.G.; Kirkbride, A.D. On large-scale flow structures in a gravel-bed river. Geomorphology 2000, 32, 417-435. [CrossRef]

259. Schvidchenko, A.; Pender, G. Macroturbulent structure of open-channel flow over gravel beds. Water Resour. Res. 2001, 37, 709-719. [CrossRef]

260. Carnie, R.; Tonina, D.; McKean, J.A.; Isaak, D.J. Habitat connectivity as a metric for aquatic microhabitat quality: Application to Chinook salmon spawning habitat. Ecohydrology 2016, 9, 982-994. [CrossRef] 
261. Waddle, T. Field evaluation of a two-dimensional hydrodynamic model near boulders for habitat calculations. River Res. Appl. 2009, 26, 730-741. [CrossRef]

262. Rhoads, B.L.; Schwartz, J.S.; Porter, S. Stream geomorphology, bank vegetation and three-dimensional habitat hydraulics for fish in midwestern agricultural streams. Water Resour. Res. 2003, 39, 1218-1230. [CrossRef]

263. Schmidt, J.C.; Rubin, D.M.; Ikeda, H. Flume simulation of recirculating flow and sedimentation. Water Resour. Res. 1993, 29, 2925-2939. [CrossRef]

264. Tamburrino, A.; Gulliver, J.S. Large flow structures in turbulent open channel flow. J. Hydraul. Res. 1999, 37, 363-380. [CrossRef]

265. Crowder, D.W.; Diplas, P. Evaluating spatially explicit metrics of stream energy gradients using hydrodynamic model simulations. Can. J. Fish. Aquat. Sci. 2000, 57, 1497-1507. [CrossRef]

266. Thompson, D.M.; Wohl, E.E.; Jarrett, R.D. Velocity reversals and sediment sorting in pools and riffles controlled by channel constrictions. Geomorphology 1999, 27, 229-241. [CrossRef]

267. Thompson, A. Secondary flows and the pool-riffle unit: A case study of the processes of meander development. Earth Surf. Process. Landf. 1986, 11, 631-641. [CrossRef]

268. Geldof, H.J.; deVriend, H.J. Distribution of main flow velocity in alternating river bends. Spec. Publ. Int. Assoc. Sedimentol. 1983, 6, 85-95.

269. Thompson, D.M.; Nelson, J.M.; Wohl, E.E. Interactions between pool geometry and hydraulics. Water Resour. Res. 1998, 34, 3673-3681. [CrossRef]

270. Howard, A.D. Modeling channel migration and floodplain sedimentation in meandering streams. In Lowland Floodplain Rivers: Geomorphological Perspectives; Carling, P.A., Petts, G.E., Eds.; John Wiley \& Sons, Ltd.: Chichester, UK, 1992; pp. 1-41.

271. Nicholas, A.P.; Walling, D.E. Modeling flood hydraulics and overbank deposition on river floodplains. Earth Surf. Process. Landf. 1998, 22, 59-77. [CrossRef]

272. Tsujimoto, T. Fluvial processes in streams with vegetation. J. Hydraul. Res. 1999, 37, 789-803. [CrossRef]

273. Poulsen, J.B.; Hansen, F.; Ovesen, N.B.; Larsen, S.E.; Kronvang, B. Linking floodplain hydraulics and sedimentation patterns along a restored river channel: River Odense, Denmark. Ecol. Eng. 2014, 66, 120-128. [CrossRef]

274. Needelman, B.A.; Kleinman, P.J.A.; Stock, J.S.; Allen, A.L. Drainage water management for water quality protection. J. Soil Water Conserv. 2010, 65, 131-136.

275. D'Ambrosio, J.L.; Williams, L.R.; Witter, J.D.; Ward, A. Effects of geomorphology, habitat, and spatial location on fish assemblages in a watershed in Ohio, USA. Environ. Monit. Assess. 2009, 148, 325-341. [CrossRef] [PubMed]

276. D'Ambrosio, J.L.; Ward, A.; Witter, J.D. Evaluating geomorphic change in constructed two-stage ditches. J. Am. Water Resour. Assoc. 2015, 51, 910-922. [CrossRef]

277. Imhof, J.G.; Fitzgibbon, J.; Annable, W.K. A hierarchical evaluation system for characterizing watershed ecosystems for fish habitat. Can. J. Fish. Aquat. Sci. 1996, 53, 312-326.

278. Wohl, E.; Angermeier, P.L.; Bledsoe, B.; Kondof, G.M.; MacDonnell, L.; Merritt, D.M.; Palmer, M.A.; Poff, N.L.; Tarboton, D. River restoration. Water Resour. Res. 2005, 41, W10301. [CrossRef]

279. Nickelson, T.E.; Solazzi, M.F.; Johnson, S.L.; Rogers, J.D. Effectiveness of selected stream improvement techniques to create suitable summer and winter rearing habitat for juvenile coho salmon (Oncorhynchus kisutch) in Oregon coastal streams. Can. J. Fish. Aquat. Sci. 1992, 49, 790-794. [CrossRef]

280. Zale, A.V.; Parrish, D.L.; Sutton, T.M. Fisheries Techniques, 3rd ed.; American Fisheries Society: Bethesda, MD, USA, 2013; p. 1009.

281. Chessman, B.C.; Royal, M.J. Bioassessment without reference sites: Use of environmental filters to predict natural assemblages of river macroinvertebrates. J. N. Am. Benthol. Soc. 2004, 23, 599-615. [CrossRef]

282. Stoddard, J.L.; Larsen, D.P.; Hawkins, C.P.; Johnson, R.K.; Norris, R.H. Setting expectations for the ecological condition of streams: The concept of reference condition. Ecol. Appl. 2006, 16, 1267-1276. [CrossRef]

283. Herring, D.; Borja, A.; Cartensen, J.; Carvalho, L.; Elliott, M.; Fled, C.K.; Heiskanen, A.-S.; Johnson, R.K.; Moe, J.; Pont, D.; et al. The European Water Framework Directive at the age of 10: A critical review of the achievements with recommendations for the future. Sci. Total Environ. 2010, 408, 4007-4019. [CrossRef] [PubMed]

(C) 2016 by the author; licensee MDPI, Basel, Switzerland. This article is an open access article distributed under the terms and conditions of the Creative Commons Attribution (CC-BY) license (http://creativecommons.org/licenses/by/4.0/). 